\title{
Strengths and limitations of in situ U-Pb titanite petrochronology in polymetamorphic rocks: An example from western Maine, USA.
}

Jesse B. Walters ${ }^{1,2^{*}}$, Alicia M. Cruz-Uribe ${ }^{2}$, Won Joon Song ${ }^{2}$, Christopher Gerbi ${ }^{2}$, Kimberley Biela $^{3}$

${ }^{1}$ Institut für Geowissenschaften, Goethe Universität, Frankfurt am Maine 60438, Germany

${ }^{2}$ School of Earth and Climate Science, University of Maine, Orono 04469, United States

${ }^{3}$ Department of Anthropology \& Geography, Colorado State University, Fort Collins 80521, United States

*Corresponding author: walters@em.uni-frankfurt.de

Disclaimer: This manuscript is a pre-print and has been submitted to the Journal of Metamorphic Geology for peer review.

\section{ABSTRACT}

Titanite is a potentially powerful $\mathrm{U}-\mathrm{Pb}$ petrochronometer that may record metamorphism, metasomatism, and deformation. Titanite may also incorporate significant inherited $\mathrm{Pb}$, the correction for which may introduce inaccuracies and result in geologically ambiguous $\mathrm{U}-\mathrm{Pb}$ dates. Here we present laser ablation inductively coupled mass spectrometry (LA-ICP-MS)-derived titanite $\mathrm{U}-\mathrm{Pb}$ dates and trace element concentrations for two banded calc-silicate gneisses from south-central Maine, USA (SSP18-1A \& -1B). Single spot common Pb-corrected dates range from 400 to 280 Ma with 12-20 Ma propagated 2SE. Titanite in sample SSP18-1B exhibit regular coreto-rim variations in texture, composition, and date. We identify four titanite populations: 1) $399 \pm$ $5 \mathrm{Ma}(95 \% \mathrm{CL})$ low $\mathrm{Y}+$ HREE cores and mottled grains, 2) $372 \pm 7$ Ma high Y + REE mantles and cores, 3) $342 \pm 6$ Ma cores with high Y + REE and no Eu anomaly, and 4) $295 \pm 6$ Ma LREEdepleted rims. We interpret the increase in titanite $\mathrm{Y}+$ HREE between ca. 400 and ca. $372 \mathrm{Ma}$ to constrain the timing of diopside fracturing and recrystallization and amphibole breakdown. Apparent $\mathrm{Zr}$-in-titanite temperatures $\left(803 \pm 36^{\circ} \mathrm{C}\right.$ at $\left.0.5 \pm 0.2 \mathrm{GPa}\right)$ and increased $\mathrm{X}_{\mathrm{Di}}$ suggest a thermal maximum at ca. $372 \mathrm{Ma}$. Population 3 domains dated to ca. $342 \mathrm{Ma}$ exhibit no Eu anomaly and are observed only in compositional bands dominated by diopside (>80 vol \%), suggesting limited equilibrium between titanite and plagioclase. Finally, low LREE and high U/Th in Population 4 titanite date the formation of hydrous phases, such as allanite, during high $\mathrm{X}_{\mathrm{H} 2 \mathrm{O}}$ fluid infiltration at ca. $295 \mathrm{Ma}$. In contrast to the well-defined date-composition-texture relationships observed for titanite from SSP18-1B, titanite grains from sample SSP18-1A exhibit complex zoning patterns and little correlation between texture, composition, and date. We hypothesize that the incorporation of variable amounts of radiogenic $\mathrm{Pb}$ from dissolved titanite into recrystallized domains resulted in mixed ages spanning 380-330 Ma. Although titanite may reliably record multiple phases of metamorphism, these data highlight the importance of considering $\mathrm{U}-\mathrm{Pb}$ data along with chemical and textural data to screen for inherited radiogenic $\mathrm{Pb}$. 


\section{INTRODUCTION}

Titanite $\left(\mathrm{Ca}\left[\mathrm{Ti}, \mathrm{Al}, \mathrm{Fe}^{3+}\right] \mathrm{SiO}_{4}[\mathrm{O}, \mathrm{OH}, \mathrm{F}, \mathrm{Cl}]\right)$ is a common accessory phase and regularly participates in reactions with major phases (see review in Kohn, 2017). Similar to zircon and monazite, the incorporation of $U$ and a variety of trace elements (e.g., $\mathrm{Zr}, \mathrm{Nb}, \mathrm{Sr}, \mathrm{Y}+\mathrm{REE})$ make titanite a potentially useful petrochronometer (Frost et al., 2000; Kohn, 2017). In particular, Zrin-titanite thermometry and TZARS (titanite with anorthite, (clino-)zoisite, rutile, and quartz) barometry allows for the estimation of both pressures $(P)$ and temperatures $(T)$ of metamorphism (Hayden et al., 2008; Kapp et al., 2009). However, the reactivity of titanite with major phases and fluids during metamorphism presents both benefits and drawbacks. Titanite U-Pb dates have been interpreted to reflect a variety of processes, including neocrystallization and growth (Castelli \& Rubatto, 2002; Corfu, 1996; Kohn \& Corrie, 2011; Rapa et al., 2017; Scott \& St-Onge, 1995; Spencer et al., 2013; Stearns et al., 2015; 2016; Verts, Chamberlain, \& Frost, 1995; Walters \& Kohn, 2017), fluid driven recrystallization or alteration (Corfu, 1996; Garber et al., 2017; Holder \& Hacker, 2019; Marsh \& Smye, 2017), Pb volume diffusion and cooling (Cherniak, 1993; Kirkland et al., 2016; Mattinson, 1978; Mezger et al., 1991; Spear \& Parish, 1996; Tucker et al., 1987), and deformation-induced recrystallization (Bonamici et al., 2015; Gordon et al., 2021; Papapavlou et al., 2018; Spencer et al., 2013; Timms et al., 2020). Additionally, disequilibrium between titanite and zircon (or quartz) may result in overestimated $\mathrm{Zr}$-in-titanite temperatures (Cruz-Uribe et al., 2018; Johnson, Cottle, \& Larson, 2020). Combined, these factors greatly complicate linking titanite zoning textures, compositions, and U-Pb dates to metamorphic, metasomatic, and tectonic processes.

Historically, titanite $\mathrm{U}-\mathrm{Pb}$ geochronometry was interpreted to date cooling, as opposed to peak metamorphism, in high grade metamorphic terranes. Early studies of $\mathrm{Pb}$ diffusion rates in titanite proposed relatively low closure temperatures $\left(T_{\mathrm{c}}\right)$ of $450-600{ }^{\circ} \mathrm{C}$ based on natural samples (e.g., Heaman \& Parrish, 1991; Gascoyne, 1986; Mattison, 1978; Mezger et al., 1993). Later, experimentally-derived $\mathrm{Pb}$-in-titanite diffusion rates determined by Cherniak (1993) suggested a $T_{\mathrm{c}}$ of $600{ }^{\circ} \mathrm{C}$ for a $100 \mu \mathrm{m}$ titanite grain cooling at a rate of $10^{\circ} \mathrm{C} / \mathrm{Myr}$ (Kohn, 2017). Variations in morphology, color, and $\mathrm{U}-\mathrm{Pb}$ ratios of titanite from contact aureoles were interpreted to reflect variable diffusive resetting of $\mathrm{Pb}$ isotope compositions (e.g., Mezger et al., 1991, 1993; Tucker et al., 1987). In contrast, studies by Corfu \& Muir (1989), Corfu \& Ayers (1991), Verts, Chamberlain, \& Frost, (1995), and others suggested that variations in titanite $\mathrm{U}-\mathrm{Pb}$ ratios may reflect multiple or protracted metamorphic and/or metasomatic events. A growing number of studies of natural titanite over the past decade suggest that volume diffusion rates of $\mathrm{Pb}$ are greatly overestimated (Gao et al., 2012; Garber et al., 2017; Hartnady et al., 2019; Holder \& Hacker, 2019; Holder et al., 2019; Kohn \& Corrie, 2011; Kohn, 2017; Smye et al., 2018; Spencer et al., 2013; Stearns et al., 2016; Walters \& Kohn, 2017). Revised estimates for Pb diffusion coefficients range from $1 \times 10^{-}$ ${ }^{20}$ to $1 \times 10^{-26}\left(\mathrm{~m}^{2} \mathrm{~s}^{-1}\right)$ (Holder, Hacker, Seward, \& Kylander-Clark, 2019; Kohn, 2017), equivalent to the experimentally derived diffusion rate for $\mathrm{Sr}$ in titanite (Cherniak, 1995). These data suggest 
that volume diffusion is unlikely to disturb $\mathrm{U}-\mathrm{Pb}$ dates in titanite metamorphosed at temperatures $<850{ }^{\circ} \mathrm{C}$ at most metamorphic time scales.

In the absence of $\mathrm{Pb}$ diffusion, disturbance of titanite $\mathrm{U}-\mathrm{Pb}$ is anticipated to occur through fluid- or deformation-induced recrystallization. Consequently, multi-generational titanite with both recrystallized and secondary domains are commonly observed (e.g., Castelli \& Rubatto, 2002; Corfu, 1996; Corfu \& Ayers, 1991; Corfu \& Muir, 1989: Garber et al., 2017; Holder \& Hacker, 2019; Johnson, Cottle, \& Larson, 2020; Spencer et al., 2013; Tucker et al., 2004; Verts, Chamberlain, \& Frost, 1995). Recrystallized zones are typically patchy to lobate and often oriented along fractures and cleavage planes, consistent with interface-coupled dissolution-reprecipitation reactions (ICDR) (Bonamici et al., 2015; Garber et al., 2017; Holder \& Hacker, 2019; Marsh \& Smye, 2017; Walters \& Kohn, 2017). During ICDR, minerals in disequilibrium with a fluid will dissolve until the chemical potential of the solid assemblage and fluid phase are equal, followed by precipitation at the reaction front once the fluid has reached super-saturation (see review in Putnis, 2009). Alternatively, depolymerization of the precursor grain may form an intermediate amorphous phase which may then recrystallize (Konrad-Schmolke et al., 2018).

One of the pitfalls of titanite $\mathrm{U}-\mathrm{Pb}$ geochronology is that significant $\mathrm{Pb}$ may be incorporated upon crystallization and a correction for the initial common $\mathrm{Pb}$ composition is often required (see discussions in Kirkland et al., 2018; Bomamici \& Blum, 2020). Isotopic homogenization of $\mathrm{Pb}$ during metamorphism is required to obtain accurate $\mathrm{U}-\mathrm{Pb}$ ages (Romer, 2001); however, $\mathrm{Pb}$ may be partially to wholly retained during ICDR, such that the initial ${ }^{207} \mathrm{~Pb} /{ }^{206} \mathrm{~Pb}$ ratio of the recrystallized domains is a mix of common $\mathrm{Pb}$ and radiogenic $\mathrm{Pb}$. Inherited radiogenic $\mathrm{Pb}$ has been identified in both neocrystallized titanite grains replacing precursor highU phases (Kirkland et al., 2017, 2018; Romer \& Rötzler, 2003), such as rutile, and in titanite recrystallized by ICDR (Castelli \& Rubatto, 2002). Even phases that typically incorporate little initial $\mathrm{Pb}$, such as monazite, may inherit old radiogenic $\mathrm{Pb}$ during ICDR recrystallization (e.g., Seydoux-Guillaume et al., 2003; Weinberg et al., 2020). Thus, the degree to which titanite dates reflect the timing of recrystallization requires careful consideration.

Here we present titanite textural observations coupled with in situ compositional and U-Pb isotopic data by electron probe microanalysis (EPMA) and laser-ablation inductively coupled mass-spectrometry (LA-ICP-MS) for two calc-silicate gneisses from western Maine, USA. In one sample (SSP18-1B), titanite textures, major and trace element compositions, and U-Pb dates strongly correlate. We identify four composition-age populations at ca. 400, 372, 342, and 295 $\mathrm{Ma}$, three of which correspond to previously dated metamorphic and igneous activity in the area. Variations in major and trace element concentration between these populations are linked to different stages of high-temperature metamorphism, deformation, and fluid infiltration. In contrast, titanite analyses from a second sample (SSP18-1A) exhibit a decoupling of U-Pb dates from textures and compositions, indicative of inherited radiogenic $\mathrm{Pb}$ from precursor titanite domains. These two samples, collected at the same outcrop, illustrate both the strengths and weaknesses of $\mathrm{U}-\mathrm{Pb}$ titanite petrochronology in polymetamorphic terranes. 


\section{GEOLOGIC SETTING}

\subsection{Regional Overview}

The geology of Central and Western Maine is dominated by extensive metasedimentary sequences of the Central Maine Trough and Connecticut Valley-Gaspé Trough, which extend from Connecticut through Newfoundland (Fig. 1A) (Hibbard et al., 2006). In the Late Silurian to Early Devonian, these sediments were deposited into extensional basins within the Ganderian margin following accretion to Laurentia (e.g., Rankin et al., 2007). These sediments were subsequently metamorphosed during the Acadian (420-350 Ma) orogeny (Robinson et al., 1998; van Staal et al., 2009), resulting in a state-wide metamorphic gradient spanning from greenschist-facies rocks in northeastern Maine to a high- $T$ migmatite terrane in southwestern Maine (Fig. 1A) (see review in Guidotti, 1989). Temperatures calculated by Holdaway et al. (1997) at $310 \mathrm{MPa}$ range up to 626-649 ${ }^{\circ} \mathrm{C}$ in the highest-grade rocks. Holdaway, Dutrow, \& Hinton (1988) noted a N-S increase in pressure, ranging from $235 \pm 25 \mathrm{MPa}$ for cordierite- and andalusite-bearing assemblages exposed in the northern lobe of the Lexington pluton to $400-500 \mathrm{MPa}$ or possibly higher for the migmatitic rocks near Lewiston (Fig. 1A). Higher $P$ is supported by estimates of 550-640 MPa at 490-540 ${ }^{\circ} \mathrm{C}$ for kyanite-bearing rocks exposed just south of the Sebago pluton (S, Fig. 1A; Thomson \& Guidotti, 1989).
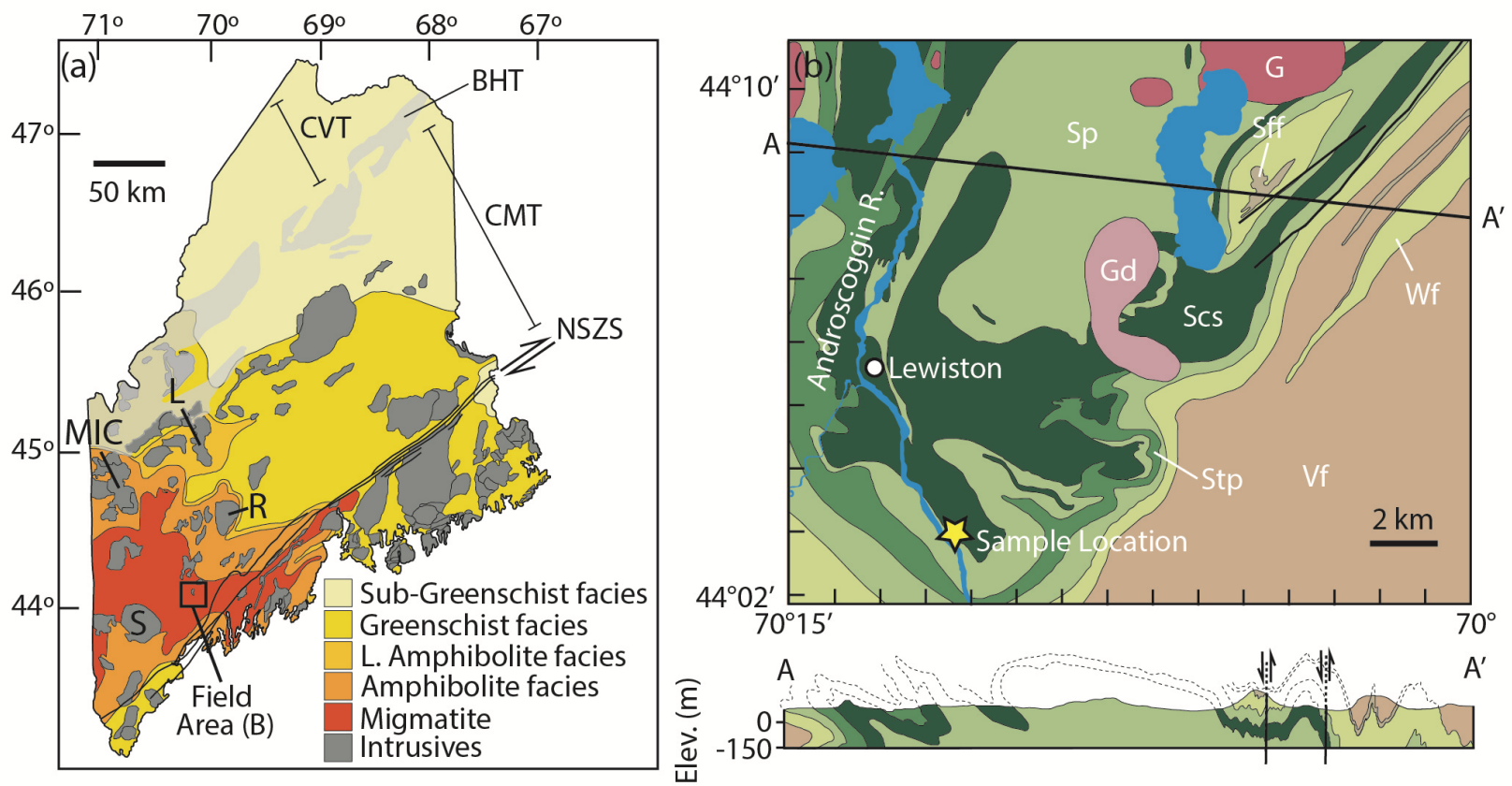

Figure 1. (a) Map of Maine showing the distribution of metamorphic grades from sub-greenschist facies rocks in the north to migmatites in the southwest (after Guidotti, 1985; with updates from Solar \& Brown, 1999). Major intrusions are highlighted, including the Lexington (L), Mooselookmeguntic (MIC), and Sebago (S) plutons. Also shown are the boundaries of the Connecticut Valley-Gaspé Trough (CVT) trough, Bronson Hill (BT) terrane, and Central Maine (CMT) trough. (b) Geologic map of the sample locality near Lewiston, Maine, and (c) Cross-section from A to A' (after Hussey, 1983). Metasedimentary units include the Vassalboro (Vf), Waterville (Wf), Smalls Falls (Sff), and Sangerville formations. The latter is divided into pelitic (Sp), calc-silicate rich (Scs), and Taylor Pond (Stp) endmembers. Granite $(\mathrm{G})$ and granodiorite $(\mathrm{Gd})$ intrusions are observed north of the sample locality. 
The complex multi-phase nature of the high-grade metamorphism has been intensely debated over the past half century (e.g., Holdaway, Dutrow, \& Hinton, 1988; Guidotti, 1970; Lux \& Guidotti, 1985; Solar \& Brown, 1999; Solar \& Tomascak, 2016). Early tectonometamorphic models for Maine describe high-grade regional metamorphism in the Acadian followed by pulses of contact metamorphism driven by pluton emplacement (see review in Guidotti, 1989). Indeed, the regional gradient is locally deflected around plutons (Fig., 1A). Additionally, pluton and dike crystallization ages range from ca. $420 \mathrm{Ma}$ for coastal plutons to 270-260 Ma for abundant gem pegmatites (Bradley et al., 2000). Dates of ca. 400 Ma throughout western and central Maine and New Hampshire are consistent with large scale high- $T$ Acadian metamorphism (Gerbi \& West, 2007; Pyle et al., 2005; Moecher, McCulla, \& Massey, 2020; Sanislav, 2011; Smith \& Barreiro, 1990; Solar et al., 1998; Wing, Ferry, \& Harrison, 2003). In the region surrounding the Mooselookmeguntic Igneous Complex (Fig. 1A), Acadian metamorphic conditions are thought to have exceeded $450 \mathrm{MPa}$ and $700{ }^{\circ} \mathrm{C}$ in the migmatites, resulting in syntectonic melt generation, percolative flow, and emplacement of granite magmas (Brown \& Solar, 1999; Johnson, Brown, \& Solar, 2003).

The timing and conditions of high-grade metamorphism to the south in the vicinity of the Sebago pluton are more enigmatic. Emplacement of the Sebago 'batholith' was long considered responsible for much of the late high-grade metamorphism in western Maine (Fig. 1A; see review in Guidotti, 1989). However, gravimetric and field mapping has revealed a much smaller Sebago pluton that sits at the core of an extensive migmatite terrane intruded by numerous smaller granitic bodies (Behn, Eusden, \& Notte, 1998; Solar \& Tomascak, 2016). Tomascak, Krogstad, \& Walker (1996) reported a U-Pb monazite thermal ionization mass spectrometry age of $293 \pm 2 \mathrm{Ma}$ for crystallization of the Sebago pluton. The crystallization ages of smaller granite and pegmatite bodies in the vicinity of the Sebago pluton range from 308 to 269 Ma (Solar \& Tomascak, 2016; Tomascak, Krogstad, \& Walker, 1996). These ages contrast with a pooled zircon rim age of $376 \pm$ $14 \mathrm{Ma}$ collected from three migmatite melanosomes (Tomascak \& Solar, 2016), suggesting that the emplacement of the Sebago pluton is not responsible for partial melting in the surrounding region. Proposed mechanisms for metamorphism and melting in broader New England invoke the development of a thick crust and extended topographic high between ca. 400 and ca. 380 Ma (Hillenbrand et al., 2021), with thermal highs between ca. 380 and ca. 330 Ma that may have been generated by lithospheric delamination and asthenospheric upwelling (e.g., Pyle et al., 2005; Moecher, McCulla, \& Massey, 2020; Robinson et al., 1998). The extent that regional, as opposed to contact, metamorphism is reflected in western Maine remains blurred by the murky temporal relationship between pluton emplacement, melting, and high-T metamorphism. Here we use titanite petrochronology to investigate the timing of high temperature metamorphism in westcentral Maine and distinguish between thermal sources.

\subsection{Sample Locality}

Three samples were collected in Lewiston, Maine, from the Sangerville formation, which in this area comprises three lithologic units: 1. Migmatic paragneiss with the dominant assemblage 
$\mathrm{Bt}+\mathrm{Ms}+\mathrm{Qtz}+\mathrm{Pl} \pm \mathrm{Sill} \pm \mathrm{Grt} \pm \mathrm{Kfs}(\mathrm{Sp}$, Fig. $1 \mathrm{~b} \& \mathrm{~S} 1), 2$. The Taylor Pond endmember paragneiss with the assemblage $\mathrm{Bt}+\mathrm{Qtz}+\mathrm{Pl} \pm \mathrm{Hbl}$ and thin interbeds of calc-silicate (Stp), and 3. Banded calc-silicate and metapsammitic gneiss (Scs, Fig. S1c; Hussey, 1983). Two samples were collected from the calcareous bands (SSP18-1A \& -1B) and a third was collected from a rare garnet-bearing horizon in the paragneiss (SS18-1D, Appendix S1). All abbreviations are after Whitney \& Evans (2010). Two larger intrusive bodies are observed to the northwest of the sample locality (Fig. 1b). The larger two-mica granite pluton $(G)$ exhibits sharp and discordant contacts with the metasediments and no obvious contact metamorphism (Hussey, 1983). Although the granite is undeformed, the fine to medium-grained granodiorite body $(\mathrm{Gd})$ is moderately to strongly foliated (Hussey, 1983). The outcrop includes at least two dike populations. The first population is parallel to the foliation of the migmatites and boudinaged (Fig. S1a \& b), whereas the second population crosscuts the foliation and exhibits sharp contacts with the host rock (Fig. S1c \& d). Pegmatite dikes are also common in the field area but are not observed in the sampled outcrop (Hussey, 1983).

\section{ANALYTICAL METHODS}

\subsection{Major and minor element analysis}

Major and minor element data on silicate phases were collected through electron probe microanalysis (EPMA) using a Cameca SX-100 electron microprobe equipped with five wavelength dispersive spectrometers, housed at the University of Maine. Standard spot analyses utilized a beam size of $5 \mu \mathrm{m}$, accelerating voltage of $15 \mathrm{keV}$, and $10 \mathrm{nA}$ beam current. On-peak counting times were $20 \mathrm{~s}$ for all elements, except for $\mathrm{Na}$, where counting time was $10 \mathrm{~s}$. Backgrounds were measured for half the on-peak counting time. Data are reported in Table S1 as the mean and 2SE of multiple analyses collected within compositionally homogenous domains. Ferric iron in garnet and clinopyroxene was determined using method \#2 of Schumacher (1991), in which all $\mathrm{Fe}$ is considered $\mathrm{Fe}^{3+}$ in titanite and epidote-group minerals. Amphibole structural formula calculations follow Leake et al. (1997) and classified following Hawthorne et al. (2012). Structural formulae of other minerals were determined by assuming a total number of cations or anions where appropriate and the methods listed are given in Appendix S1.

Qualitative and quantitative compositional maps were also collected by EPMA. Qualitative garnet (Fig. S2) and full thin section (Fig. S3) X-ray intensity maps were collected using a $20 \mathrm{keV}$ accelerating voltage, $100 \mathrm{nA}$ beam current, and a dwell time of $30 \mathrm{~ms}$. Single- and multi-phase quantitative maps were collected using at a $15 \mathrm{keV}$ accelerating voltage, $100 \mathrm{nA}$ beam current, and $300 \mathrm{~ms}$ dwell time with a focused beam and a step size of $2 \mu \mathrm{m}$. X-ray intensity maps were quantified using 15-36 spot analyses per phase and the program XMapTools (Lanari et al., 2014; 2018).

\subsection{Titanite $\mathrm{U}-\mathrm{Pb}$ geochronology and trace element analysis}

In situ titanite $\mathrm{U}-\mathrm{Pb}$ and trace element analyses were conducted on polished thin sections by laser-ablation inductively coupled plasma mass spectrometry (LA-ICP-MS) in the the 
University of Maine MAGIC (MicroAnalytical Geochemistry and Isotope Characterization) Lab over two separate sessions for samples SSP18-1A (Session 1) and -1B (Session 2). Titanite analysis locations are shown in Figures $\mathrm{S} 4$ to $\mathrm{S} 6$. Trace element and $\mathrm{U}-\mathrm{Pb}$ data were collected using an ESI NWR193 ${ }^{\text {UC }}$ excimer laser ablation system coupled to an Agilent 8900 ICP-MS using $25 \mu \mathrm{m}$ round spots with a beam energy density of $\sim 3 \mathrm{~J} \mathrm{~cm}^{-2}$ and repetition rate of $4 \mathrm{~Hz}$. Plagioclase, alkali feldspar, and clinopyroxene in textural equilibrium were analyzed for unradiogenic ${ }^{207} \mathrm{~Pb} /{ }^{206} \mathrm{~Pb}$. These analyses were conducted using a beam diameter of $50 \mu \mathrm{m}$, a $2 \mathrm{~J} \mathrm{~cm}^{-2}$ beam energy density, and $4 \mathrm{~Hz}$ repetition rate. All analyses consisted of $13 \mathrm{~s}$ of background collection during laser warm up, $40 \mathrm{~s}$ of ablation, and $10 \mathrm{~s}$ of washout. Monitored isotopes and dwell times (ms) were ${ }^{29} \mathrm{Si}(5),{ }^{43} \mathrm{Ca}(1),{ }^{44} \mathrm{Ca}(1),{ }^{49} \mathrm{Ti}(5),{ }^{56} \mathrm{Fe}(1),{ }^{88} \mathrm{Sr}(1),{ }^{89} \mathrm{Y}(1),{ }^{90} \mathrm{Zr}(5),{ }^{93} \mathrm{Nb}(1),{ }^{137} \mathrm{Ba}$ (1), ${ }^{139} \mathrm{La} \mathrm{(1)},{ }^{140} \mathrm{Ce}(1),{ }^{141} \mathrm{Pr}(1),{ }^{146} \mathrm{Nd}(1),{ }^{147} \mathrm{Sm}(1),{ }^{153} \mathrm{Eu}(1),{ }^{157} \mathrm{Gd}(1),{ }^{159} \mathrm{~Tb}$ (1), ${ }^{163} \mathrm{Dy}(1)$, ${ }^{165} \mathrm{Ho}(1),{ }^{166} \mathrm{Er}$ (1), ${ }^{169} \mathrm{Tm}(1),{ }^{172} \mathrm{Yb}(1),{ }^{175} \mathrm{Lu}(1),{ }^{178} \mathrm{Hf}(1),{ }^{181} \mathrm{Ta}(1),{ }^{202} \mathrm{Hg}(40),{ }^{204} \mathrm{~Pb}(60),{ }^{206} \mathrm{~Pb}$ (40), ${ }^{207} \mathrm{~Pb}(60),{ }^{208} \mathrm{~Pb}(30),{ }^{232} \mathrm{Th}(10),{ }^{235} \mathrm{U}(10)$, and ${ }^{238} \mathrm{U}(10)$. Silicon contents of $14.00( \pm 0.16$ $2 \mathrm{~s})$ and $14.07( \pm 0.202 \mathrm{~s})$ wt. \% determined by EPMA were used for internal standardization for SSP18-1A and -1B, respectively, to calculate trace element mass fractions. The Iolite4 software package of Paton et al. (2011) was utilized for data reduction; mass fractions were calculated using the Trace Elements DRS, and isotope ratios were calculated using the U-Pb Geochronology DRS. U-Pb dates were calculated using IsoplotR (Vermeesch, 2018) and pooled dates were determined using the maximum likelihood algorithm of Ludwig (1998).

Analyses of unknowns were bracketed by those of titanite reference materials MKED1 (1518.87 \pm 0.32 Ma; Spandler et al., 2016), BLR-1 (1047.1 \pm 0.4 Ma; Aleinikoff et al., 2007), and McClure Mountain (523.26 $\pm 0.65 \mathrm{Ma}$; Schoene \& Bowring, 2006). Analyses of NIST SRM610, NIST SRM612, and GSD-1G glasses (Pearce et al., 1997; Jochum et al., 2011) were conducted for trace element determination. MKED1 was used as the primary reference material for $\mathrm{U}-\mathrm{Pb}$ isotope ratios and $\mathrm{Ca}, \mathrm{Ti}$, and $\mathrm{Zr}$ mass fractions, whereas NIST610 was used as the primary reference material for all other trace elements. All titanite $\mathrm{U}-\mathrm{Pb}$ isotope and trace element data for unknowns are reported in Tables S2 and S3, respectively. Single spot dates are given with uncertainties reported as $2 \mathrm{SE}$. whereas the uncertainties of pooled dates are reported as the $95 \%$ confidence interval corrected for overdispersion (Vermeesch, 2018).

Measured ${ }^{207} \mathrm{~Pb} / 206 \mathrm{~Pb}$ ratios of clinopyroxene from SSP18-1A and -1B are $0.9654 \pm 0.0393$ (2SE, $\mathrm{n}=5$ ) and $0.9554 \pm 0.0495(\mathrm{n}=10)$, respectively. In contrast, feldspar ${ }^{207} \mathrm{~Pb} /{ }^{206} \mathrm{~Pb}$ ratios are $0.8730 \pm 0.0064(\mathrm{n}=15)$ and $0.8781 \pm 0.0061(\mathrm{n}=10)$, respectively. Common $\mathrm{Pb}$ isotope analyses are reported in Table $\mathrm{S} 4$. We estimate that $2-20 \%$ of the measured $\mathrm{Pb}$ is inherited 'common' unradiogenic $\mathrm{Pb}(2207 \mathrm{~Pb}$, Table $\mathrm{S} 2)$. As a result, dates that are uncorrected, corrected using the two-stage crustal evolution model of Stacey \& Kramers (1975), and corrected with measured feldspar or pyroxene ${ }^{207} \mathrm{~Pb} /{ }^{206} \mathrm{~Pb}$ ratios are equal within their respective uncertainties. Given the higher $\mathrm{Pb}$ concentrations in feldspar relative to clinopyroxene and smaller scatter we calculated all dates using the feldspar $\mathrm{Pb}$ ratios. We discuss potential systematic inaccuracies introduced by our preferred method of common $\mathrm{Pb}$ correction in section 7.2. 
The measured dates and trace element concentrations for secondary reference materials are consistent with published values and are reported in Tables S5 and S6, respectively. Weighted mean ages of $1044 \pm 14 \mathrm{Ma}(\mathrm{n}=20, \mathrm{MSWD}=0.71)$ and $1065 \pm 23 \mathrm{Ma}(\mathrm{n}=16, \mathrm{MSWD}=2.40)$ for BLR-1 calculated for our two sessions are within uncertainty of the published dates. These data suggest that ages are both precise and true relative to reference values within $\pm 1-2 \%$ uncertainty $(95 \% \mathrm{CI})$. Additional dates of $516 \pm 37(\mathrm{n}=10, \mathrm{MSWD}=2.38)$ and $537 \pm 16(\mathrm{n}=10, \mathrm{MSWD}=$ 0.83 ) for the McClure Mountain titanite are also consistent with the published age. We find that the trace element concentrations of NIST SRM612 and GSD-1G are within 3 and $14 \%$, respectively, of reference values from Jochum et al. (2011). Zr concentrations exhibit a larger bias ( 6 and $17 \%$, respectively); however, MKED1 titanite was used as a reference material for $\mathrm{Zr}$ and the bias is likely due to matrix differences. Our trace element concentrations for BLR are less consistent with published values (Table S6). For example, our Zr concentrations are $\sim 270 \mu \mathrm{g} \mathrm{g}^{-1}$ higher than those reported by Mazdab (2009). It is likely these differences represent trace element heterogeneity in the BLR-1 titanite.

\subsection{Titanite LA-ICP-MS Mapping}

Trace element maps of a titanite grain from SSP18-1A were also collected at the University of Maine. Maps were collected using fast washout tubing and an ESI dual concentric injector ICPMS torch. Analytical conditions consisted of a square $7 \times 7 \mu \mathrm{m}$ spot, $88 \mu \mathrm{m} \mathrm{s}^{-1}$ raster rate, $5 \mathrm{~J} \mathrm{~cm}^{-2}$ beam energy density, $200 \mathrm{~Hz}$ repetition rate, and a $\mathrm{He}$ carrier gas flow rate of $1100 \mathrm{~mL} / \mathrm{min}$. Monitored isotopes and dwell times (ms) were ${ }^{28} \mathrm{Si}(1),{ }^{49} \mathrm{Ti}(1),{ }^{89} \mathrm{Y}(1),{ }^{90} \mathrm{Zr}(1),{ }^{202} \mathrm{~Pb}(20),{ }^{207} \mathrm{~Pb}$ (30), and ${ }^{238} \mathrm{U}$ (10). The total ICP-MS duty cycle of $80 \mathrm{~ms}$ was synchronized to the laser pulse width following Van Malderen et al. (2018) and van Elteren et al. (2019) to achieve pixel dimensions of $7 x 7 \mu \mathrm{m}$. Two lines of BLR titanite were rastered at the same conditions before and after the unknown titanite grain. The time-resolved signals were processed using the VizualAge UComPbine and Trace Elements data reduction schemes in Iolite (v4) using ${ }^{28} \mathrm{Si}$ (14.2 wt. \%) as the internal standardization element for mass fraction calculations. Trace element maps were produced using CellSpace in Iolite4 (Paton et al., 2011; Paul et al., 2012; Woodhead et al., 2007). Final maps were reprocessed in XMapTools (Lanari et al., 2014; 2018; Raimondo et al., 2017).

\subsection{Major mineral LA-ICP-MS analysis}

In addition to titanite, minor and trace element analyses (Session 3) were conducted on diopside, amphibole, epidote group minerals, plagioclase, and alkali feldspar and are reported in Table S7. Analyses of diopside, amphibole, and epidote group minerals were conducted with a spot diameter of 30 or $40 \mu \mathrm{m}, \mathrm{a} \sim 3 \mathrm{~J} \mathrm{~cm}^{-2}$ beam energy density, and a repetition rate of $8 \mathrm{~Hz}$, whereas feldspar analyses were conducted with a $40 \mu \mathrm{m}$ spot diameter, a $6.7 \mathrm{~J} \mathrm{~cm}^{-2}$ beam energy density, and repetition rate of $8 \mathrm{~Hz}$. A gas flow rate of $800 \mathrm{~mL} / \mathrm{min}$ of He was used, and a 'Squid'type signal smoother was employed. Measured isotopes and dwell times (ms) were ${ }^{27} \mathrm{Al}(3),{ }^{29} \mathrm{Si}$ (3), ${ }^{44} \mathrm{Ca}(3),{ }^{49} \mathrm{Ti}(30),{ }^{56} \mathrm{Fe}(20),{ }^{88} \mathrm{Sr}(14),{ }^{89} \mathrm{Y} \mathrm{(5),}{ }^{90} \mathrm{Zr}(10),{ }^{93} \mathrm{Nb}$ (10), ${ }^{137} \mathrm{Ba}(20),{ }^{139} \mathrm{La}(20)$,

${ }^{140} \mathrm{Ce}(15),{ }^{141} \mathrm{Pr}(20),{ }^{146} \mathrm{Nd}(20),{ }^{147} \mathrm{Sm}(20),{ }^{153} \mathrm{Eu}(20),{ }^{157} \mathrm{Gd}(20),{ }^{159} \mathrm{~Tb}(20),{ }^{163} \mathrm{Dy}(20),{ }^{165} \mathrm{Ho}$ (20), ${ }^{166} \mathrm{Er}(20),{ }^{169} \mathrm{Tm}(20),{ }^{172} \mathrm{Yb}(20),{ }^{175} \mathrm{Lu}(20),{ }^{178} \mathrm{Hf}(20),{ }^{181} \mathrm{Ta}(20)$, and ${ }^{208} \mathrm{~Pb}(10)$. All 
analyses consisted of $40 \mathrm{~s}$ ablation with $15 \mathrm{~s}$ background collection during laser warm up and 10 $\mathrm{s}$ of washout on the ICP-MS. Unknown analyses were bracketed with analyses NIST SRM610, NIST SRM612, and GSD1G reference glasses. We used NIST SRM610 as the primary reference material and the data were reduced using Iolite (v4). Silicon contents measured by EPMA were used as the internal standards and are reported in Table S7. Trace element concentrations for plagioclase and amphibole were calculated using compositional extremes. Major mineral LAICP-MS results are summarized in Table S7.

\subsection{Electron backscatter diffraction analysis}

For electron backscatter diffraction (EBSD) analysis of titanite grains in Sample SSP181A, the sample was polished mechanically with $0.3 \mu \mathrm{m}$ alumina suspension and chemically in 0.02 $\mu \mathrm{m}$ colloidal silica suspension, and then was coated with a thin layer of carbon to prevent electron charging. EBSD patterns of titanites were collected in the Tescan Vega II Scanning Electron

Microscope equipped with an EDAX-TSL EBSD system at the University of Maine. Operating conditions for the EBSD analysis were an acceleration voltage of $20 \mathrm{kV}$, a working distance of 25 $\mathrm{mm}$, a beam current of $\sim 6 \mathrm{nA}$, a $70^{\circ}$ sample tilt, high-vacuum conditions, and a step size of $2 \mu \mathrm{m}$.

Collected EBSD patterns were indexed using the crystallography data of a natural titanite sample (E2312; Hawthorne et al., 1991). EDAX-TSL OIM Analysis 6 software was used to postprocess titanite EBSD data based on confidence index (CI) and neighboring orientations. Non- and poor-indexed pixels $(\mathrm{CI}<0.02)$ were replaced with well-indexed neighboring pixels of $\mathrm{CI} \geq 0.02$. The indexing rate is more than $99.8 \%$. Relative misorientation maps display the minimum misorientation relative to a reference orientation (see Figs. S7-8).

\section{PETROGRAPHY AND MAJOR ELEMENT CHEMISTRY}

Below we describe the mineral assemblages, textures, and major element compositions for calc-silicate samples SSP18-1A and -1B and infer possible reactions. Additional petrographic description is given for the metapelitic sample (SSP18-1D) in Appendix S1, along with photomicrographs (Fig. S9) and garnet EPMA transects (Fig. S10).

\subsection{Calc-silicate sample SSP18-1A}

Sample SSP18-1A is a gneiss with alternating calcsilicate and metapsammitic bands comprising the peak mineral assemblages $\mathrm{Di}+\mathrm{Kfs}+\mathrm{Pl}+\mathrm{Ttn}+\mathrm{Ap}$ and $\mathrm{Bt}+\mathrm{Pl}$, respectively (Fig. $2 \mathrm{a}-\mathrm{f})$. Minor and trace minerals in the calcsilicate band include pyrrhotite, calcite, and zircon, whereas only zircon is present in the psammitic bands. Plagioclase (An40-46), alkali feldspar, diopside, titanite, and apatite in the calcsilicate band exhibit a granular texture (Fig. 2a-b), consistent with equilibrium. Major mineral compositions are summarized in Figure S11. Backscattered electron (BSE) images of alkali feldspar reveal intersecting linear high Ba zones (up to 1 wt. \%, Fig. 2c). Diopside grains exhibit slight undulatory and patchy Fe-Mg zoning in BSE (Fig. 2e). Calcite is rare ( $<<1$ vol \%) and quartz is not observed. The absence of quartz and rarity calcite in the peak assemblage is consistent with the reaction proposed by Ferry (1976): 

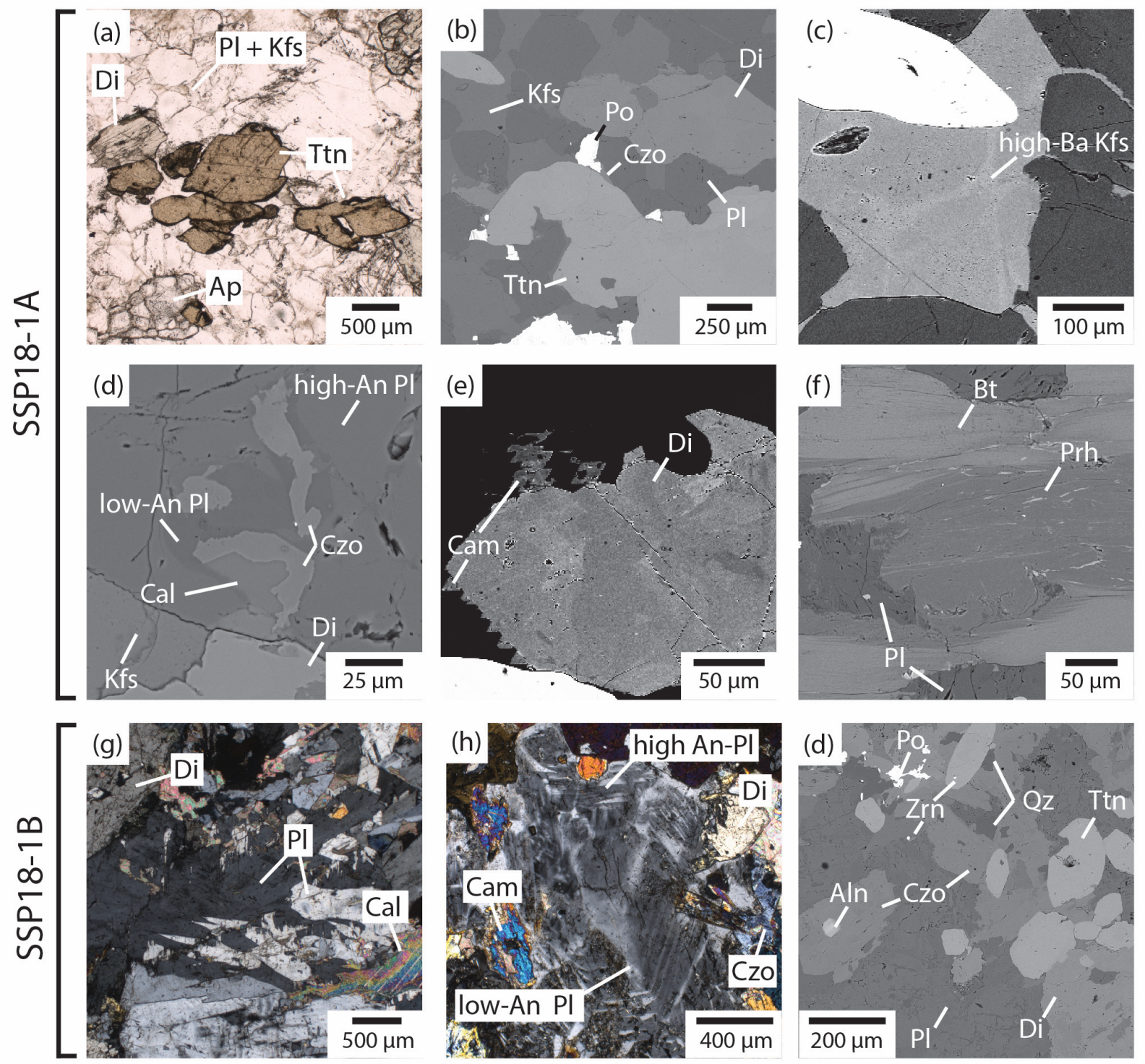

Figure 2. Plane polarized light (a), cross-polarized light (g-h), and backscattered electron (BSE, b-f, d) images of minerals and textures in sample SSP18-1A and -1B. SSP18-1A: (a) Large titanite grains adjacent to diopside, plagioclase, and alkali feldspar, (b) Granular texture of plagioclase, alkali feldspar, and diopside adjacent to titanite, with small grains of clinozoisite and pyrrhotite, (c) High-Ba BSE-bright linear features observed in alkali feldspar, (d) A patch of intergrown clinozoisite, low-An $\mathrm{Pl}$, and calcite adjacent to high-An plagioclase, (e) Calcic-amphibole and complex lobate zoning in diopside, and (f) prehnite replacing biotite in a metapsammitic band. SSP18-1B: (g) Complex and sharply interlocking plagioclase grains are observed along with diopside and plagioclase, (h) oscillatory zones high-An plagioclase is cut by veins of low-An plagioclase, and (d) clinozoisite with allanite cores and rare quartz overprint earlier formed diopside, titanite, and plagioclase.

(1) $\mathrm{Qz}+\mathrm{Cal}+\mathrm{Tr}=\mathrm{Di}+\mathrm{CO}_{2}+\mathrm{H}_{2} \mathrm{O}$

While alkali feldspar is abundant (Fig. S3), we observe no evidence of precursor K-bearing phases, such as biotite, in the calcsilicate band itself.

Retrograde minerals are observed only locally and make up $<1-2$ vol \% or less of the sample. First, a second phase of An 06 plagioclase and clinozoisite replace An $40-46$ plagioclase and 
calcite (Fig. 3D). Second, diopside grains are rimmed by calcic amphibole, which range in composition from Mg-hornblende to actinolite (Fig. 2e \& S6a-b). These textures are consistent with the following reactions in the $\mathrm{CaO}-\mathrm{MgO}-\mathrm{Al}_{2} \mathrm{O}_{3}-\mathrm{SiO}_{2}-\mathrm{H}_{2} \mathrm{O}-\mathrm{CO}_{2}$ system:

(2) $\mathrm{An}+\mathrm{Cal}+\mathrm{H}_{2} \mathrm{O}=\mathrm{CzO}+\mathrm{CO}_{2}$

(3) $\mathrm{Di}+\mathrm{En}+\mathrm{Qz}+\mathrm{H}_{2} \mathrm{O}=\mathrm{Tr}$

In particular, retrogression via Reactions 2 and 3 were likely limited by the rarity of calcite and quartz. In the psammitic bands, biotite grains are partially replaced by prehnite (Fig. 2f). No clear $\mathrm{Mg}$ - or Fe-rich product phase is observed, and possible reactions require mobilization of these components into a fluid phase.
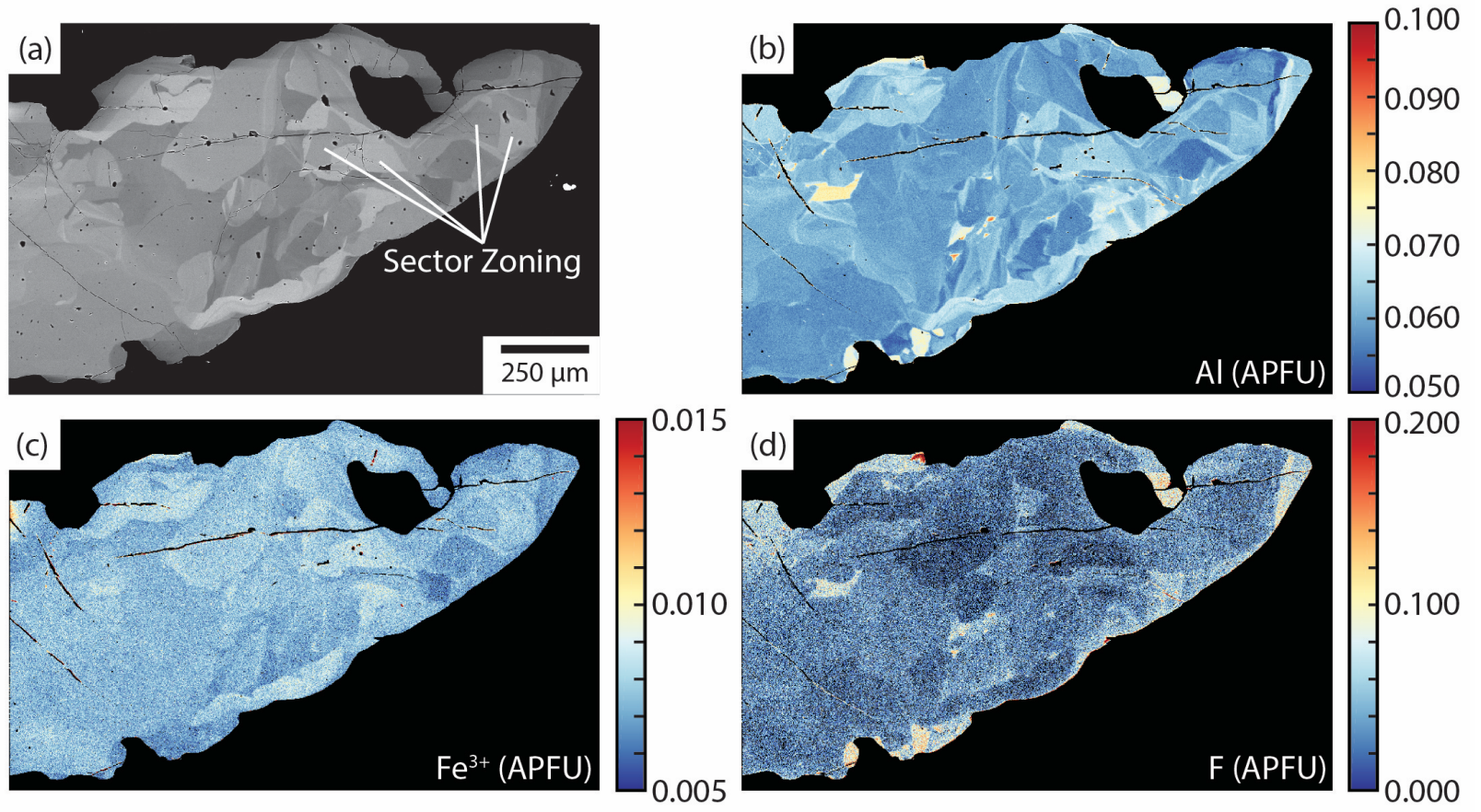

Figure 3. (a) Back scattered electron image and quantitative maps of (b) $\mathrm{Al}$, (c) $\mathrm{Fe} 3+$, and (e) $\mathrm{F}$ concentrations in a titanite grain from SSP18-1A (Grain 2, Fig. S5). Concentrations are given in atoms per formula unit (APFU) and composition maps are produced by XMapTools (Lanari et al., 2014; 2018).

Titanite $(\sim 10$ vol $\%)$ in the calcsilicate band occur as large $(\leq 2.5 \mathrm{~mm})$ grains. Misorientation maps show up to $10^{\circ}$ of internal deformation that sweep gradationally across grains and larger misorientations occur associated with fractures, grain boundaries, and twinning (Figs. S7-S8). Misorientations are not correlated with compositional zoning in BSE (Figs. S4-S5). Titanite BSE images reveal a complex patchwork of overlapping zones with sharp to gradational boundaries (Figs. S4-S5). Sector zones, with their characteristic fir-tree shape, and cyclical zones are observed in some grains (Fig. 3a). Titanite endmember fractions range from $\mathrm{Ttn}_{92}$ to $\mathrm{Ttn}$ 94, with considerable variation in $\mathrm{Al}, \mathrm{Fe}^{3+}$, and $\mathrm{F}$ shown in major element compositional maps (Fig. 3b-c). Aluminum and $\mathrm{Fe}^{3+}$ are positively correlated within grain interiors, whereas BSE dark rims exhibit elevated $\mathrm{Al}+\mathrm{F}$ and low $\mathrm{Fe}^{3+}$. The observed zoning is thus consistent with the substitution (Al, 
$\mathrm{Fe})^{3+}+(\mathrm{OH}, \mathrm{F})^{-}=\mathrm{Ti}^{3+}+\mathrm{O}^{2-}($ Kohn, 2017). Possible titanite forming reactions proposed by Frost et al. (2000) and Rapa et al. (2017) are:

(4) $\mathrm{Qz}+\mathrm{Rt}+\mathrm{Cal}=\mathrm{Ttn}+\mathrm{CO}_{2}$,

(5) $\mathrm{Ti}-\mathrm{Phl}+\mathrm{Cal}+\mathrm{Qz}=\mathrm{Kfs}+\mathrm{Tr}+\mathrm{Ttn}+\mathrm{H}_{2} \mathrm{O}+\mathrm{CO}_{2}$,

(6) $\mathrm{Ti}-\mathrm{Phl}+\mathrm{Cal}+\mathrm{Qz}=\mathrm{Kfs}+\mathrm{Di}+\mathrm{Ttn}+\mathrm{H}_{2} \mathrm{O}+\mathrm{CO}_{2}$.

Additionally, if $X_{\mathrm{CO} 2}$ was sufficiently low during prograde metamorphism, the reaction

(7) $\mathrm{Qz}+\mathrm{Rt}+\mathrm{Zo}=\mathrm{Ttn}+\mathrm{An}$,

may have occurred. Other phases, such as amphibole and epidote group minerals, may contain significant Ti (Frei et al., 2004; Hawthorne et al., 2012) and their breakdown during prograde metamorphism may also promote titanite formation. However, the lack of prograde reaction textures and inclusions in titanite preclude clear petrographic identification of initial titanite forming reactions.

\subsection{Calcsilicate Sample SSP18-1B}

Sample SSP18-1B is a gneiss with alternating diopside- or plagioclase-rich bands (Fig. $\mathrm{S} 12$ ). The peak assemblage $\mathrm{Di}+\mathrm{Kfs}+\mathrm{Pl}+\mathrm{Cal}+\mathrm{Ttn}$ is observed (Fig. 2g-i \& 4). Minor and trace phases include pyrrhotite and zircon. Calcite is rare, making up $<10$ vol $\%$ of plagioclase-rich bands. Plagioclase grains exhibit irregular interlocking grain boundaries with sharp spire-like intergrowths (Fig. 2g) and more rarely cyclical zones (Fig. 2h). These grains are often fractured an infilled by lower An plagioclase. Compositional maps and spot analyses reveal a range from $\mathrm{An}_{28}$ to $\mathrm{An}_{80}$ (Figs. $4 \mathrm{~d} \& \mathrm{~S} 11$ ). Diopside grains exhibit intense fracturing and rehealing textures: Early diopside exhibits the composition $\mathrm{Di}_{53-54}$ which increases to $\mathrm{Di}_{58-70}$ in the later fracture-fill clinopyroxene (Fig. 4b). Rare amphibole inclusions are observed in larger diopside grains, consistent with Reaction 1. Alkali feldspar is observed in fractured regions of diopside (Fig. 4), suggesting the reaction

(8) $\mathrm{Phl}+\mathrm{Cal}+\mathrm{Qz}=\mathrm{Tr}+\mathrm{Kfs}+\mathrm{CO}_{2}+\mathrm{H}_{2} \mathrm{O}$,

which may have occurred following the fracturing of the early diopside grains. However, no inclusions of biotite or relict matrix grains are observed.

Extensive amphibole and clinozoisite retrogression are observed in sample SS18-1B (Fig. 2h). Amphibole compositions range from Mg-hornblende to actinolite from core to rim. Allanite occurs as cores in clinozoisite, suggesting LREE depletion from the reactive bulk composition as retrogression progressed (Fig. 2i). Epidote compositions range from $\mathrm{Ep}_{29}$ to $\mathrm{Ep}_{60}$, with higher $\mathrm{Fe}$ contents adjacent to diopside (Fig. 4c). In some areas, clinozoisite is associated with quartz (Fig. $2 \mathrm{i})$, suggesting the hydration reaction

(9) $\mathrm{Di}+\mathrm{An}+\mathrm{H}_{2} \mathrm{O}=\mathrm{Qz}+\mathrm{Czo}+\mathrm{Tr}$.

Elsewhere, clinozoisite has nucleated adjacent to calcite, consistent with the decarbonationhydration Reaction 2 (Fig. 4a). 

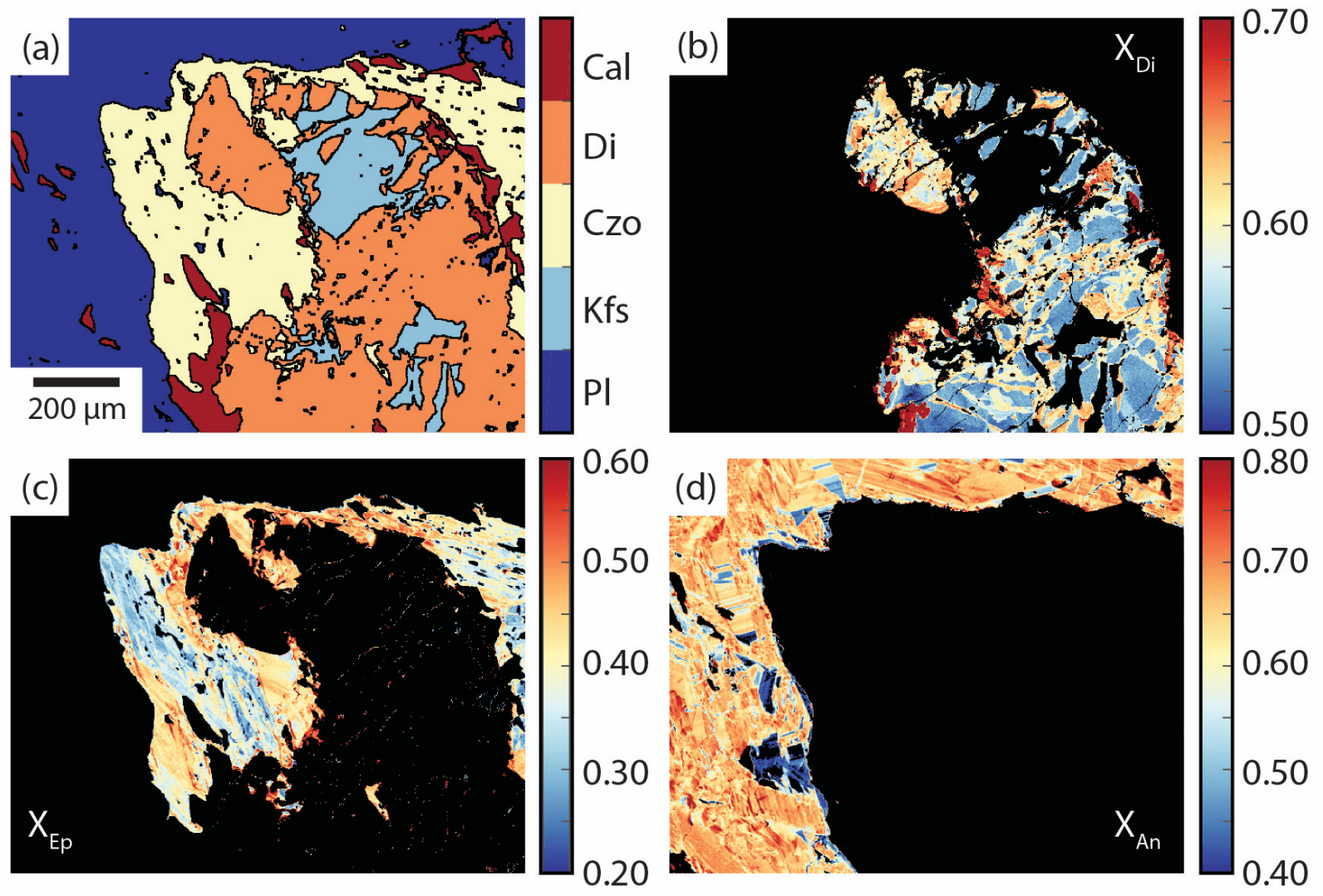

Figure 4. (a) Phase map and quantitative compositional maps of the endmember fractions of (b) diopside (XDi) in clinopyroxene, (c) epidote (XEp) in clinozoisite/epidote, and (D) anorthite (XAn) in plagioclase in sample SSP18-1B. Maps are produced using the XMapTools software package (Lanari et al., 2014; 2018).

Titanite grains $(1-2$ vol \%) in sample SSP18-1B are relatively small $(<800 \mu \mathrm{m})$ and lenticular in habit. Titanite grains are observed primarily in the matrix and as rare inclusions in diopside. The interiors of some rare grains exhibit oscillatory zoning or patchy cores, both with and without sectors (Fig. S6). However, most grains exhibit regular core to rim zoning, with BSE dark cores observed in some grains, followed by a BSE bright mantle and a BSE dark rim (Fig. S6). Many grains exhibit only bright cores and dark rims. Titanite compositions range from $\mathrm{Ttn}_{94}$ to in the cores to $\operatorname{Ttn}_{87}$ in the rims.

\section{TRACE ELEMENT CHEMISTRY}

Feldspar and diopside are the dominant peak metamorphic phases in our samples. Analyses of plagioclase reveal relatively high concentrations of $\mathrm{Sr}\left(160-1684 \mu \mathrm{g} \mathrm{g}^{-1}\right)$, Ba (17.7-944 $\mu \mathrm{g} \mathrm{g}^{-}$

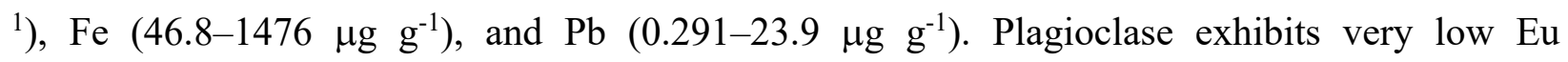
concentrations $\left(0.001-0.570 \mu \mathrm{g} \mathrm{g}^{-1}\right)$ but displays a positive Eu anomaly relative to $\mathrm{Sm}$ and $\mathrm{Gd}$, which are below detection. Alkali feldspar in SSP18-1A exhibits elevated Ba (5296-7064 $\mu \mathrm{g} \mathrm{g}^{-1}$ ), Sr (790-1054 $\left.\mu \mathrm{g} \mathrm{g}^{-1}\right), \mathrm{Pb}\left(33.4-66.7 \mu \mathrm{g} \mathrm{g} \mathrm{g}^{-1}\right)$, and Fe (18.4-40.0 $\left.\mu \mathrm{g} \mathrm{g}^{-1}\right)$, with a positive Eu 

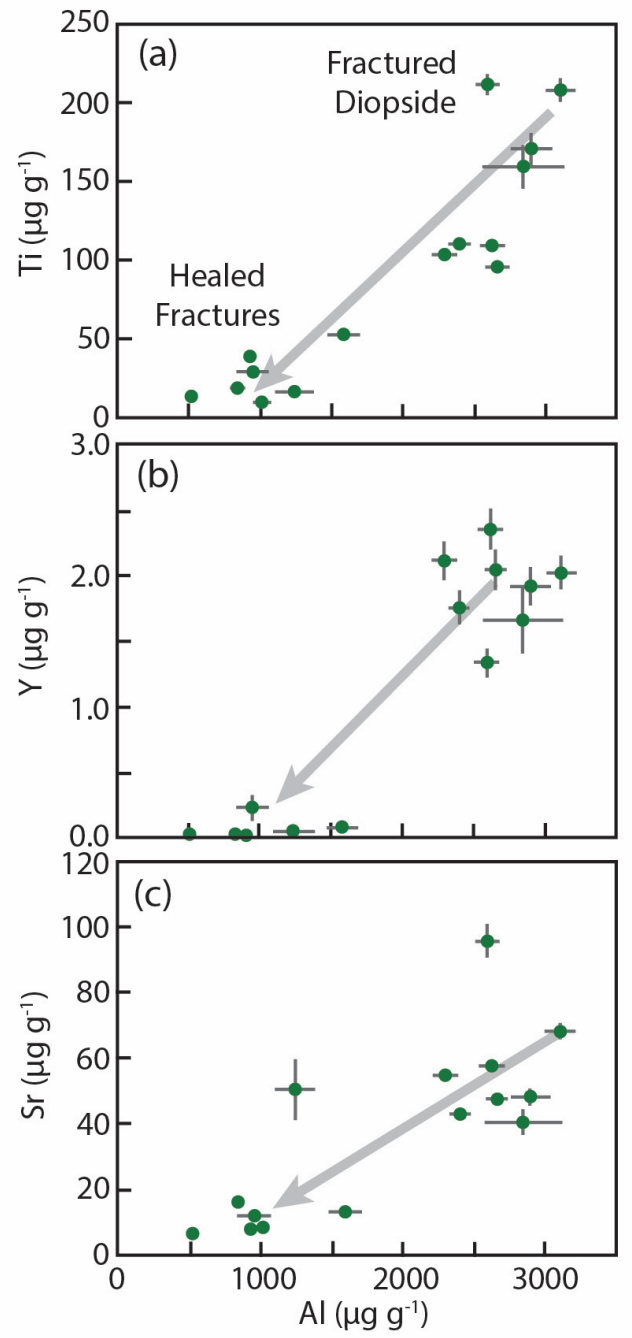

Figure 5. LA-ICP-MS analyses of diopside showing (a) Ti, (b) Y, and (c) Sr concentrations plotted relative to Al. Gray arrows indicate the trends from analyses of fractured low $\mathrm{X}_{\mathrm{Di}}$ fragments and high $\mathrm{X}_{\mathrm{Di}}$ recrystallized domains.

anomaly. Diopside grains have elevated Ti $(9.5-212 \mu \mathrm{g}$ $\left.\mathrm{g}^{-1}\right)$ and $\mathrm{Sr}\left(0.86-95.6 \mu \mathrm{g} \mathrm{g}{ }^{-1}\right)$, relative to other trace elements, and exhibits high $\mathrm{Y}+\mathrm{HREE}$ relative to LREE. In Sample SSP18-1B, Ti, Y (+HREE), and Sr concentrations decrease between early fractured high $\mathrm{X}_{\mathrm{Di}}$ and healed low $\mathrm{X}_{\mathrm{Di}}$ diopside domains (Figs. 4 \& 5).

Texturally late amphibole and epidote group minerals were also analyzed. Amphibole compositions range between $\mathrm{Ti}\left(730-2635 \mu \mathrm{g} \mathrm{g}^{-1}\right), \mathrm{Sr}(8.84-37.8 \mu \mathrm{g}$ $\left.\mathrm{g}^{-1}\right)$, and $\mathrm{Y}\left(9.73-68.9 \mu \mathrm{g} \mathrm{g}^{-1}\right)$ and are depleted in LREE relative to HREE. Analyses of epidote and clinozoisite in Sample SSP18-1B reveal high Sr (690-1595 $\mu \mathrm{g} \mathrm{g}^{-1}$ ) and $\mathrm{Pb}\left(30.8-138 \mu \mathrm{g} \mathrm{g}^{-1}\right)$ relative to other trace elements, elevated LREE relative to HREE, and a strong positive $\mathrm{Eu}$ anomaly $\left(\mathrm{Eu} / \mathrm{Eu}^{*}=2.1-9.7\right)$. Analysis of an allanite core in epidote revealed high LREE (e.g., Ce 37 wt \%), Th (2024 $\left.\mu \mathrm{g} \mathrm{g}^{-1}\right)$, U (487 $\left.\mu \mathrm{g} \mathrm{g}^{-1}\right)$, and $\mathrm{Ti}\left(1288 \mu \mathrm{g} \mathrm{g}^{-1}\right)$, with sharply decreasing abundance from the allanite core through the epidote mantle and rim.

Titanite grains exhibit a wide range of compositions. For example, $\mathrm{Fe}, \mathrm{Y}$, and $\mathrm{Sr}$ concentrations range from 1227 to $2526 \mu \mathrm{g} \mathrm{g}^{-1}, 94$ to $5175 \mu \mathrm{g} \mathrm{g}^{-1}$, and 25.8 to 156 $\mu \mathrm{g} \mathrm{g}{ }^{-1}$, respectively (Fig. 6). Rare Earth element patterns vary considerably between and within samples. In SSP18-1B, titanite REE patterns range from steep MREE to HREE slope with high LREE to analyses with flat MREE to HREE and low LREE (Fig. 7a). Some domains exhibit no Eu anomaly whereas others exhibit a strong negative Eu anomaly. In contrast, sample SSP18-1A REE patterns range from relatively flat with strong negative $\mathrm{Eu}$ anomalies to MREE depleted patterns with positive Eu anomalies (Fig. 7b). The correlation of these trace element patterns with age are discussed in Section 7.

\section{ZR-IN-TITANITE THERMOMETRY}

Zr-in-titanite temperatures were calculated for samples SS18-1A and -1B using the formulation of Thomas et al. (2010). Temperatures were calculated at $500 \mathrm{MPa}$ with an associated 2 s uncertainty of $\pm 200 \mathrm{MPa}$, corresponding to the 300-700 MPa range predicted here of possible pressures proposed for various stages of metamorphism in western Maine (Holdaway, Dutrow, \& 

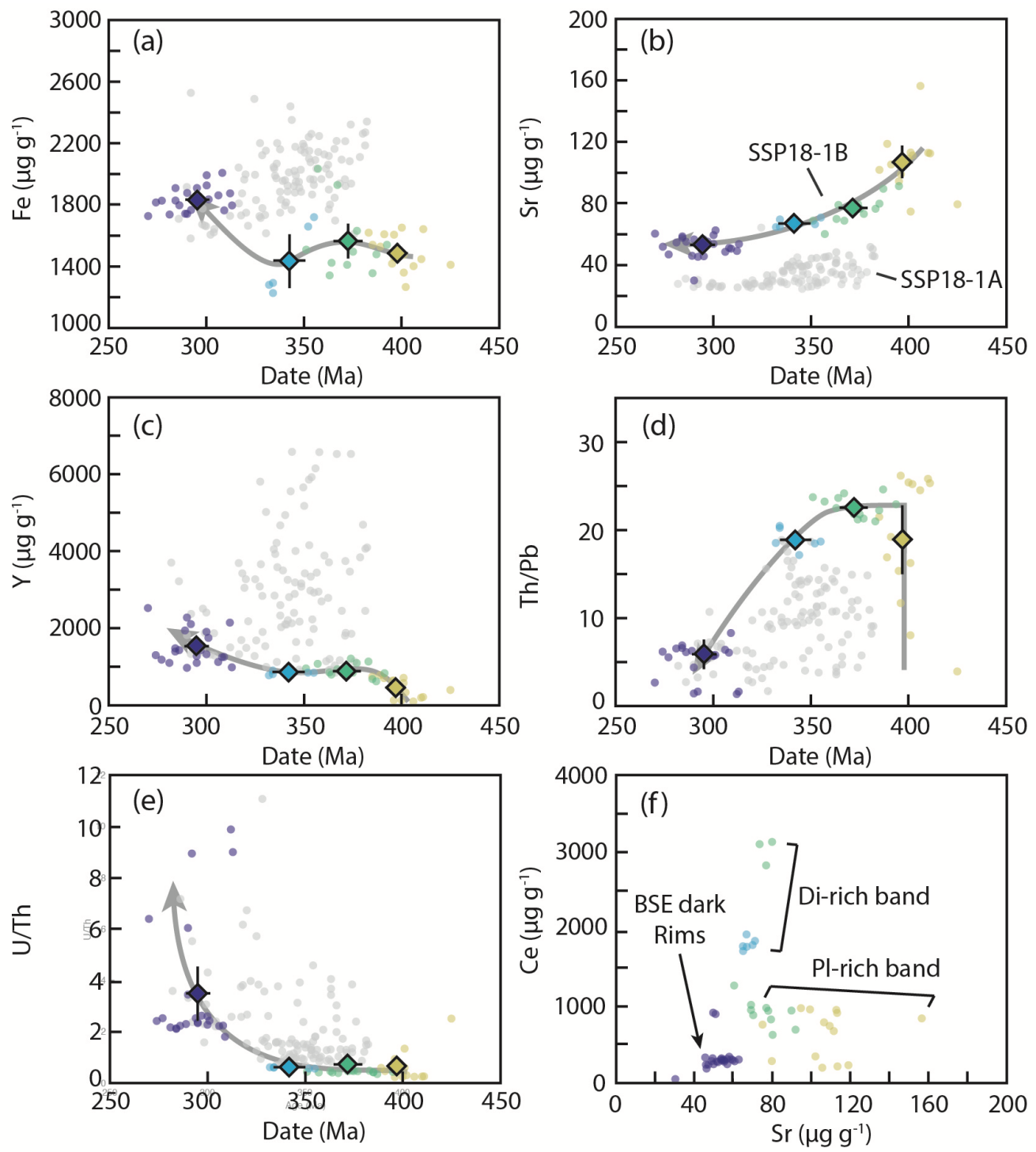

Figure 6. LA-ICP-MS analyses of titanite showing concentrations of (a) Fe, (b) Sr, (c) Y, (d) Th/Pb, and (e) U/Th plotted relative to apparent age, as well as (f) Ce concentrations plotted against Sr. Data for sample SSP18-1B are color coded by Population: 1) yellow, 2) green, 3) blue, and 4) purple, whereas data for sample SSP18-1A are given in grey. Arrows indicate trends with time for sample SS18-1B. Data plotted in $\mathrm{f}$ are labeled according to titanite location (diopside-rich or plagioclase-rich bands) and texture (BSE dark rims).

Hinton, 1988; Holdaway et al., 1997; Thomson \& Guidotti, 1989; this study). The $a_{\mathrm{TiO}}$ of titanitebearing rutile-absent metamorphic rocks is thought to be $>0.5$ (Chambers \& Kohn, 2012, Ghent \& Stout, 1984); therefore, we assume a value of $0.75 \pm 0.25$ (2s). Temperatures were also corrected for $a_{\mathrm{CaTiSiO}}$ using an ideal activity model and our measured $X_{\mathrm{Ttn}}$ and $2 \mathrm{~s}$ uncertainties of $0.93 \pm 0.01$ and $0.91 \pm 0.05$ for samples SSP18-1A and -1B, respectively. All calculations assume $a_{\mathrm{SiO} 2}$ and $a_{\mathrm{ZrSi} 4}$ of unity. Zircon grains are rare in the calc-silicate band of SSP18-1A, whereas zircon inclusions in titanite are common in SSP18-1B (Fig. 2d \& S6). Quartz is only observed in SSP18$1 \mathrm{~B}$ associated with texturally late clinozoisite and sample SSP18-1A is quartz-absent; therefore, the majority of our Zr-in-titanite temperatures for SSP18-1A and those calculated from interior 


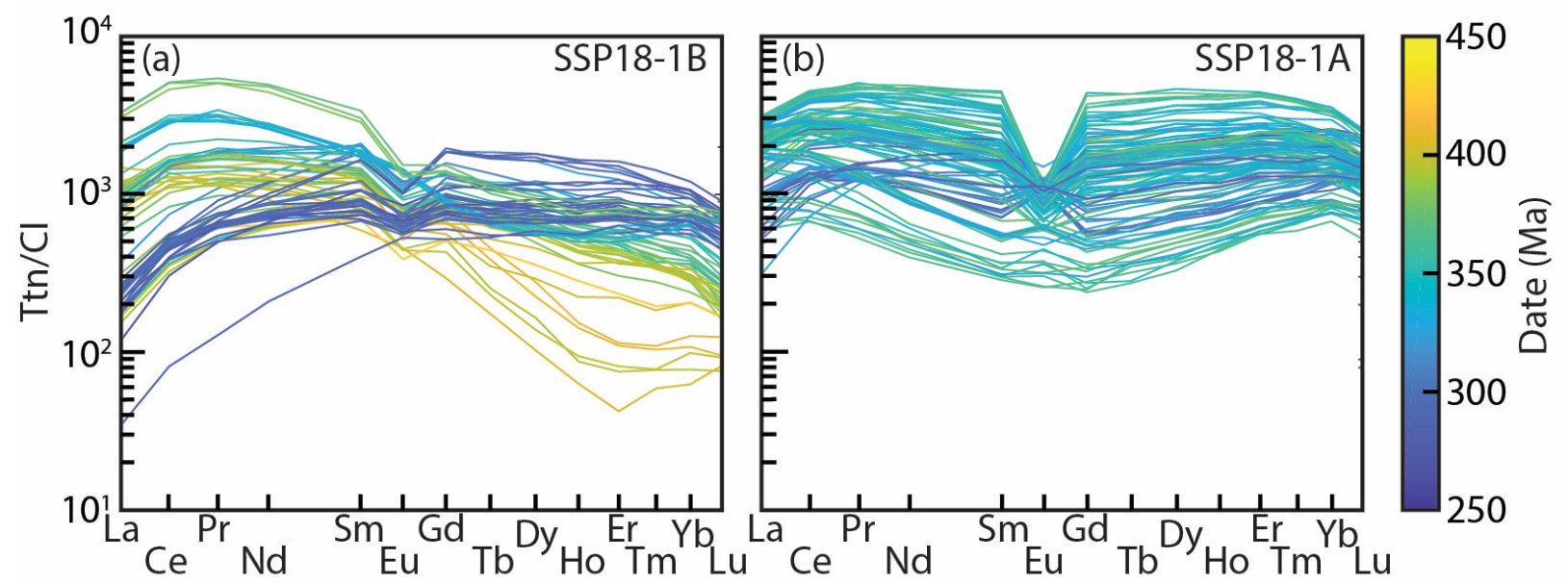

Figure 7. Rare earth element diagrams of titanite LA-ICP-MS analyses for (a) samples SSP18-1B and (b) -1A. Concentrations on the y-axis are normalized relative to the CI chondrite values of Sun \& McDonough (1989). The xaxis is scaled relative to ionic radius and analyses are color coded according to single spot common Pb corrected dates.

zones in SSP18-1B are likely maxima. Temperatures are reported in Table S8, and all temperatures are quoted in text are reported to the nearest $5^{\circ} \mathrm{C}$.

Zr-in-titanite temperatures in samples SSP18-1A and -1B are 690-790 and $690-830{ }^{\circ} \mathrm{C}$, respectively. Associated $2 \mathrm{~s}$ uncertainties range from \pm 20 to $22{ }^{\circ} \mathrm{C}$. Hayden et al. (2008) argued that low $\mathrm{Zr}$ sector zones most closely approximate equilibrium and their calibration was based on low Zr-sectors when observed. We only observe a $6{ }^{\circ} \mathrm{C}$ difference in calculated temperature between high- and low-Zr sectors in SSP18-1A, which is well within the calculated uncertainty. In addition to Zr-in-titanite thermometry, we use the garnet-biotite thermometer of Ferry \& Spear (1976) with the Berman (1990) garnet activity model and garnet-aluminosilicate-quartzplagioclase (GASP) barometer using the calibration of Hodges \& Crowley (1985) to estimate conditions of $630-700 \mathrm{MPa}$ and $725-740{ }^{\circ} \mathrm{C}$ for relatively unmodified garnet cores from metapelite sample SSP18-1D (for details see Appendix S1, Fig S11). This estimate is consistent with the $690-830{ }^{\circ} \mathrm{C}$ range calculated by $\mathrm{Zr}$-in-titanite thermometry, sillimanite inclusions in garnet, and field observations, such as the distinct lack of thermal haloes around granite dikes and abundant leucosomes in the more pelitic portions of the sampled outcrop (Fig. S1d).

\section{TITANITE PETROCHRONOLOGY}

Titanite single spot common $\mathrm{Pb}$-corrected dates range from 400 to $280 \mathrm{Ma}$ with $12-20 \mathrm{Ma}$ propagated 2SE. In sample SSP18-1B, titanite displays distinctive trends in minor and trace element composition and rare earth element (REE) pattern with date (Fig. 6). Zoning in BSE is largely concentric, with the oldest dates obtained from rare BSE dark cores and the youngest ages obtained from BSE dark rims (Fig. S6). Analyses show an increase in Y and Fe through time, a decrease in $\mathrm{Sr}$, variable $\mathrm{Th} / \mathrm{Pb}$, increasing $\mathrm{U} / \mathrm{Th}$, and a decoupling of Ce from $\mathrm{Sr}$ (Fig. 6). Chondrite normalized REE patterns also reveal increasing HREE through time, followed by a late depletion in LREE (Fig. 7a). These trends correspond to distinct zones in BSE, revealing four texturechemistry-date populations (Fig. 8). First, BSE dark cores are dated to $399 \pm 14$ and exhibit low Y 
$+\mathrm{Fe}+\mathrm{Zr}$ concentrations, and a steep MREE to HREE slope (Fig. 6 \& 7a). Two titanite grains (1 and 2, Fig. S6a-b) show complicated internal zoning with mottled textures and occasional minor oscillations. These grains display dates, Y + Fe concentrations, and low HREE consistent with BSE dark core domains; however, some analyses of these regions give dates less than $<380 \mathrm{Ma}$ which may indicate disturbance of the U-Pb system. If the oldest analyses of mottled zones are included with BSE dark zones, a pooled age of $397 \pm 5$ is calculated for Population 1 (Table 1). BSE dark cores are surrounded by BSE bright mantles; however, in most grains only BSE bright cores are observed. The BSE bright domains are divided into Populations 2 and 3. Population 2 domains give a pooled date of $372 \pm 7$ and have elevated $Y$ and $\mathrm{Zr}$ concentrations, a shallower MREE to HREE slope, and clear Eu anomaly (Table 1, Fig. 7a). Population 3 domains were observed in two grains with angular BSE bright cores and gives a pooled date of $342 \pm 8$. Unlike Population 2, Population 3 domains exhibit lower $\mathrm{Zr}$ and $\mathrm{Sr}$ concentrations and display no Eu anomaly (Table 1, Fig. 7a). Finally, Population 4 BSE dark rim and mantle domains are dated to $295 \pm 6$ and display high Y, low $\mathrm{Zr}+\mathrm{Sr}$, and a distinctive depletion in the LREE (Table 1, Fig. 7a).

Table 1. Summary of titanite date, trace element concentration, and Zr-in-titanite temperature for sample SSP18-1B.

\begin{tabular}{|c|c|c|c|c|c|c|c|c|c|}
\hline \multirow[b]{2}{*}{ Population } & \multicolumn{4}{|c|}{ Pooled Concordia Date ${ }^{a}$} & \multicolumn{3}{|c|}{$\begin{array}{l}\text { Mean Trace Element } \\
\text { Concentrations }(\mu g \mathrm{~g}-1)\end{array}$} & \multicolumn{2}{|c|}{$\begin{array}{l}\text { Zr-in-Titanite } \\
\text { Temperature }\end{array}$} \\
\hline & Mean & $95 \% \mathrm{CL}$ & $n$ & MSWD & $\mathrm{Y}$ & $\mathrm{Zr}$ & $\mathrm{Sr}$ & Wtd. Mean & $2 \sigma^{\mathrm{b}}$ \\
\hline 1 & 397 & 5 & 14 & 1.00 & 446 & 349 & 106 & 744 & 44 \\
\hline 2 & 372 & 7 & 13 & 2.50 & 895 & 935 & 76 & 803 & 36 \\
\hline 3 & 342 & 8 & 6 & 1.70 & 834 & 458 & 67 & 764 & 1 \\
\hline 4 & 295 & 6 & 26 & 2.70 & 1510 & 368 & 53 & 749 & 34 \\
\hline
\end{tabular}

${ }^{a}$ Model 1 Discordia (Vermeesch, 2018), ${ }^{b}$ weighted standard deviation adjusted for overdispersion

In contrast to sample SSP18-1B, most analyses of titanite grains from SSP18-1A do not display clear trends with date. Most analyses produce a cloud of data in ${ }^{238} \mathrm{U} /{ }^{206} \mathrm{~Pb}-{ }^{207} \mathrm{~Pb} /{ }^{206} \mathrm{~Pb}$ space with associated dates spanning a range of 380 and $330 \mathrm{Ma}$ (Fig. 8b). No correlation is observed between age and $\mathrm{Y}$ and Fe concentrations and REE pattern for dates within this range (Figs. 6 \& 7). A comparison of analysis location, zoning in BSE, and trace element concentrations reveals zones with similar composition and varying date, but also crosscutting zones with distinct trace element compositions and overlapping dates (Figs. S4-S5). The latter case is demonstrated by LA-ICP-MS mapping of a titanite grain from SSP18-1A: Internal zones show large variation in $\mathrm{Y}$ and $\mathrm{Zr}$ concentrations at a nearly constant ${ }^{207} \mathrm{~Pb} /{ }^{206} \mathrm{~Pb}$ of $0.07-0.10$ (Fig. 9). Like SSP18-1B, titanite grains in SSP18-1A display young BSE dark rims with lower Zr and a pooled date of 306 $\pm 7 \mathrm{Ma}(\mathrm{MSWD}=3.50, n=19)$. These rim domains exhibit more restricted, and generally lower, $\mathrm{Fe}$, and Y relative to older interior domains, but do not display the LREE depletion observed in SSP18-1A (Figs. 6, 7, \& 9). Rim domains consistently exhibit higher ${ }^{207} \mathrm{~Pb} /{ }^{206} \mathrm{~Pb}$ ratios $(>0.10)$ 


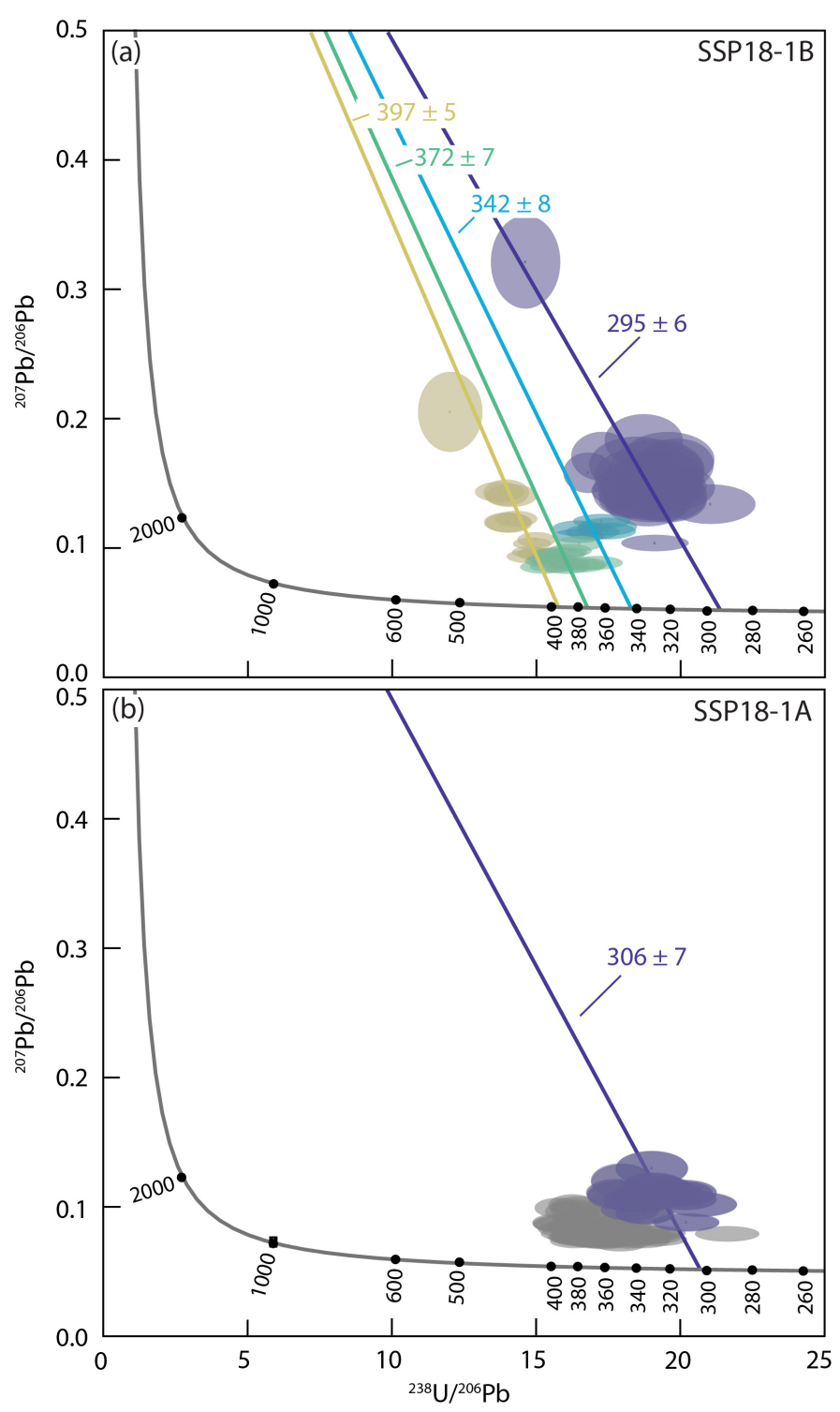

Figure 8. Tera-Wassserburg diagrams for LA-ICP-MS analyses of titanite from samples (a) SSP18-1B and (b) -1A. Isochrons and pooled dates are shown with associated $95 \% \mathrm{CL}$ as calculated in IsoplotR (Vermeesch, 2018). Isochrons and error ellipses are color coded relative to Populations 1 (yellow), 2 (green), 3 (blue), and 4 (purple) for sample SSP18-1B (a). An isochron for analyses of BSE dark rims in SSP18-1A is also shown in purple (b). Note that assignment to each isochron was based on texture (e.g., core, mantle, rim) and composition, as a result a single analysis of a titanite grain interior SSP18-1A is not included in the rim regression despite occurring to the right of the isochron. relative to interior domains $(<0.10)$, suggesting a greater incorporation of unradiogenic initial $\mathrm{Pb}$ (Fig. 9). Occasional sector zoning is observed in titanite grains from SSP18-1A (Fig. 3a). Bright and dark sectors in BSE exhibit equivalent ${ }^{207} \mathrm{~Pb} /{ }^{206} \mathrm{~Pb}$ ratios and $\mathrm{U}, \mathrm{Sr}$, and $\mathrm{Nb}$ concentrations, suggesting these elements were not partitioned between sectors during crystallization. In contrast, $\mathrm{Y}$ and REE are enriched in BSE bright sectors by $150-200 \%$ and $<50 \%$, respectively.

\section{DISCUSSION}

\subsection{Linking titanite dates to metamorphic processes}

Titanite in sample SSP18-1B reveal a 105 Myr history of metamorphism from ca. 400 to ca. 295 Ma. Titanite in this sample largely exhibit core-to-rim zoning in BSE, with a decrease in date between cores and rims (Fig. S6), consistent with multiple stages of secondary overgrowth (e.g., Castelli \& Rubatto, 2002). Beginning with the earliest stage, Population 1 BSE dark cores and mottled domains are dated to ca. $400 \mathrm{Ma}$ and give a range of 690-785 ${ }^{\circ} \mathrm{C}$ for maximum Zr-in-titanite temperatures. There is little textural evidence of this early metamorphic event. Initial neocrystallization of titanite may have formed by the breakdown of rutile or biotite (Reactions 4-6). No inclusions of biotite or rutile are observed in titanite or other phases, suggesting that these phases were not present following prograde metamorphism at ca. $400 \mathrm{Ma}$. Amphibole and clinozoisite/epidote in calcsilicate rocks may also contain 10s to $1000 \mathrm{~s}$ of $\mu \mathrm{g} \mathrm{g}^{-1}$ of $\mathrm{Ti}$ (Table S7). The prograde breakdown of these phases may have also promoted Population 

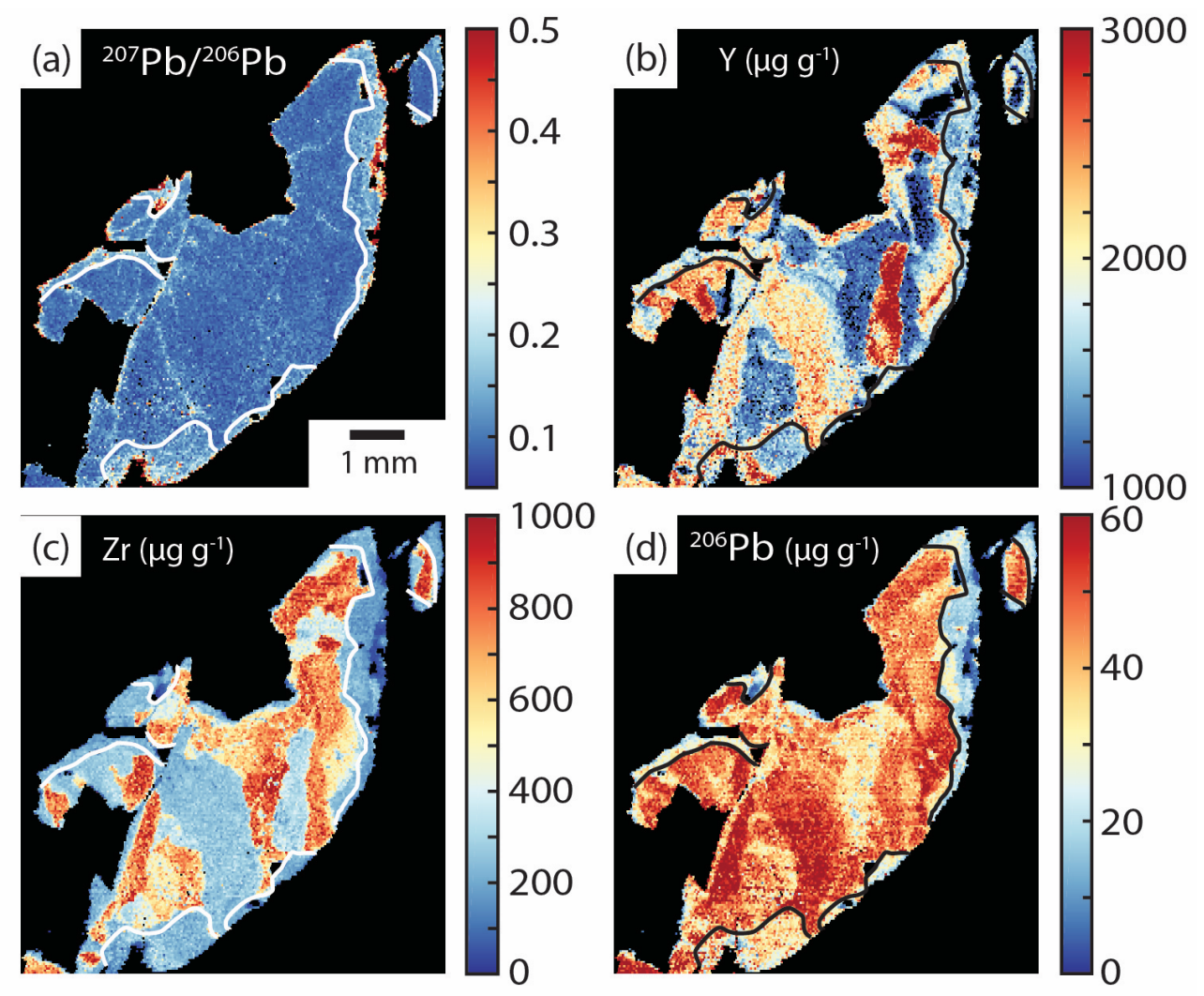

Figure 9. LA-ICP-MS maps of (a) ${ }^{207} \mathrm{~Pb} /{ }^{206} \mathrm{~Pb}$, (b) $\mathrm{Y}$, (c) $\mathrm{Zr}$, and (d) ${ }^{206} \mathrm{~Pb}$ for a titanite grain from sample SSP18-1A. The white and black lines mark the boundary between young ${ }^{207} \mathrm{~Pb} /{ }^{206} \mathrm{~Pb}$ enriched rims and older interior domains. Figures were reprocessed with the XMapTools software package (Lanari et al., 2014; 2018).

1 titanite crystallization. The wide range in $\mathrm{Th} / \mathrm{Pb}$ ratios (5-25) observed in these domains (Fig. $6 \mathrm{~d})$ does give some indication of possible reactions at ca. $400 \mathrm{Ma}$. Allanite will strongly fractionate $\mathrm{Th}$ from $\mathrm{Pb}$ and the prograde breakdown of allanite may have increased the $\mathrm{Th} / \mathrm{Pb}$ ratio of coexisting titanite (Fig. 10b). Considerable variation in LREE concentrations is also observed in Population 1 domains, consistent with allanite-breakdown (Fig. 7a) (Johnson, Cottle, \& Larson, 2021). Our explanation is consistent with rock-buffered fluid compositions anticipated for prograde of calc-silicates: In a closed-system, prograde decarbonation reactions buffer the fluid from low $\mathrm{X}_{\mathrm{CO} 2}$ conditions to higher $\mathrm{X}_{\mathrm{CO} 2}$ conditions, resulting in the breakdown of early prograde epidote group minerals to form An-rich plagioclase (Fig. 10a) (e.g., Ferry, 1976; Groppo et al., 2017; Rapa et al., 2017).

The transition between $400 \mathrm{Ma}$ (Pop. 1) and $372 \mathrm{Ma}$ (Pop. 2) domains is marked by a sharp increase in Y+HREE (Fig. 6c \& 7a) and a maximum Zr-in-titanite temperature of $\sim 800{ }^{\circ} \mathrm{C}$ (Table 1). Garnet and amphibole may partition Y+HREE from titanite (Garber et al., 2017). Garnet is not observed as a prograde phase and only rarely occurs in the psammitic to pelitic bands in our field area; therefore, garnet breakdown at $372 \mathrm{Ma}$ is unlikely to have enriched titanite in these elements. Instead, amphibole is observed together with titanite as inclusions in diopside but does not occur in the peak assemblage. We suggest that amphibole, rather than garnet, breakdown at ca. $372 \mathrm{Ma}$ led to the increase in Y+HREE (Fig. 10b). Diopside grains also reveal a protracted metamorphic 


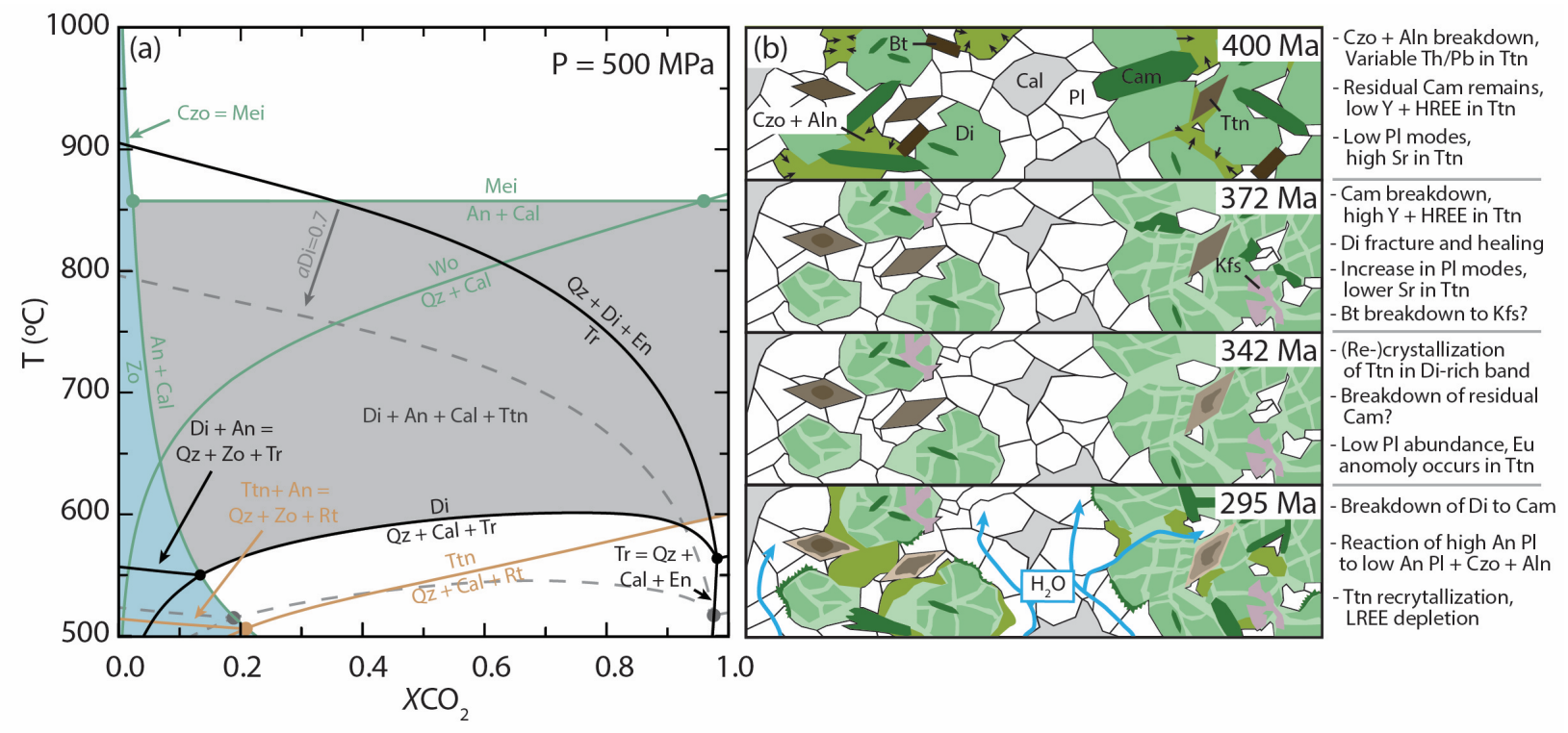

Figure 10. (a) Petrogenetic T- $\mathrm{X}_{\mathrm{CO} 2}$ grid calculated at $500 \mathrm{MPa}$ for the $\mathrm{CaO}-\mathrm{Al}_{2} \mathrm{O}_{3}-\mathrm{SiO}_{2}-\mathrm{H}_{2} \mathrm{O}-\mathrm{CO}_{2}$ (green), $\mathrm{CaO}-\mathrm{MgO}-$ $\mathrm{Al}_{2} \mathrm{O}_{3}-\mathrm{SiO}_{2}-\mathrm{H}_{2} \mathrm{O}-\mathrm{CO}_{2}$ (black), and $\mathrm{CaO}-\mathrm{Al}_{2} \mathrm{O}_{3}-\mathrm{SiO}_{2}-\mathrm{TiO}_{2}-\mathrm{H}_{2} \mathrm{O}-\mathrm{CO}_{2}$ (orange) systems calculated in Perple_X (Connolly, 2005). Reactions involving $\mathrm{MgO}$ are also calculated with an activity of diopside $(a \mathrm{Di})$ of 0.70 . The grey field denotes the high-T moderate to high $\mathrm{X}_{\mathrm{CO} 2}$ assemblage $\mathrm{Di}+\mathrm{An}+\mathrm{Cal}+\mathrm{Ttn}$, whereas the blue field denotes the stability field of Zo (or Czo). (b) Shows a schematic diagram illustrating the reaction sequences inferred from mineral textures, compositions, and titanite trace element compositions between ca. 400 and ca. $295 \mathrm{Ma}$ (see text for details).

history of an early low $\mathrm{X}_{\mathrm{Di}}$ phase followed by fracturing and recrystallization of diopside with higher $\mathrm{X}_{\mathrm{Di}}$ (Fig. $4 \mathrm{~b}$ ). In addition to a decrease in $\mathrm{Al}$ and $\mathrm{Fe}$ between fractured and healed diopside, our analyses also reveal lower in Ti, Y, and Sr in healed domains (Fig. 5). Given that titanite is the only high-T phase to partition $\mathrm{Y}+\mathrm{HREE}$ over pyroxene in our rocks, mass balance requires recrystallization of fractured diopside formed at ca. 400 contributed to Y+HREE enrichment in titanite at ca. 372 Ma. Population 2 titanite likely formed through a combination of neocrystallization, as well as secondary overgrowth on Population 1 domains, driven by residual amphibole breakdown and diopside recrystallization (Fig. 10b). Lower activities of diopside shift the diopside-in reactions to lower $\mathrm{T}$ (Fig. 10a). The increase in $\mathrm{X}_{\mathrm{Di}}$ and high maximum $\mathrm{Zr}$-intitanite temperatures require that peak metamorphic conditions occurred at ca. $372 \mathrm{Ma}$.

Population 3 domains at ca. $342 \mathrm{Ma}$ exhibit no Eu anomaly and lower maximum Zr-intitanite temperature $\left(\sim 765^{\circ} \mathrm{C}\right)$ relative to Population 2 domains (Fig. $7 \mathrm{a} \&$ Table 1). Absolute Eu concentrations increase by $\sim 30 \mu \mathrm{g} \mathrm{g}^{-1}$ between ca. 372 and ca. $342 \mathrm{Ma}$, whereas Sm and Gd concentrations are constant. Plagioclase breakdown will release Eu relative to other REE. Plagioclase in SSP18-1B contains 1098-1282 $\mu \mathrm{g} \mathrm{g}^{-1}$ of Sr, and plagioclase breakdown would release significant $\mathrm{Sr}$ in addition to Eu. Titanite $\mathrm{Sr}$ concentrations decrease through time across all domains (Fig. 6b). Prograde metamorphism of calc-silicates at temperatures below scapolite stability produce increasing plagioclase modes at the expense of other Ca-bearing phases, such as calcite and clinozoisite (e.g., Ferry, 1976; Groppo et al., 2017; Walters \& Kohn, 2017). We suggest that the decrease in titanite $\mathrm{Sr}$ concentrations with time represents increasing plagioclase modes. Therefore, plagioclase breakdown at ca. $342 \mathrm{Ma}$ cannot account for the lack of the Eu anomaly in 
Population 3 titanite domains. Interestingly, Population 3 titanite were only observed in a diopsiderich ( $\sim 80$ vol. $\%$ ) band (Fig. 10b). Plagioclase incorporates Sr, but not LREE, whereas other phases, such as epidote group minerals, incorporate both $\mathrm{Sr}$ and LREE. Exchange between titanite and plagioclase will produce variable Sr but LREE will remain unaffected. Population 2 and 3 titanite domains from the diopside-rich band exhibit variable $\mathrm{Fe}$, low $\mathrm{Sr}$, and high $\mathrm{Ce}$, whereas Population 3 domains from the plagioclase-rich band exhibit a variable $\mathrm{Sr}$ concentrations and restricted Ce concentrations (Fig. 6a \& f). We suggest that poor intragrain mobility of trace elements between the diopside- and plagioclase-rich bands resulted in local equilibrium. Additionally, local equilibria must have controlled titanite (re-)crystallization at ca. $342 \mathrm{Ma}$, as domains of this date are not observed in the plagioclase-rich bands (Fig. 10b).

Finally, BSE dark Population 4 rims dated to ca. $295 \mathrm{Ma}$ exhibit low $\mathrm{Sr}, \mathrm{Th} / \mathrm{Pb}$, and LREE, high $\mathrm{U} / \mathrm{Th}$, and deep negative Eu anomaly (Figs. 6 \& 7a). We link these trace element characteristics to infiltration of a hydrous during this final stage of titanite (re-)crystallization (Fig. $10 \mathrm{~b})$. A decrease in $\mathrm{X}_{\mathrm{CO} 2}$ to $<0.10\left(\mathrm{X}_{\mathrm{H} 2 \mathrm{O}}>0.90\right)$ would stabilize clinozoisite over plagioclase and result in the breakdown of diopside to amphibole, both of which texturally overprint the earlier higher $\mathrm{X}_{\mathrm{CO} 2} \mathrm{Di}+\mathrm{Kfs}+\mathrm{Pl}+\mathrm{Cal}$ assemblage in our samples. Clinozoisite-epidote Sr concentrations (771-1595 $\mu \mathrm{g} \mathrm{g}^{-1}$ ) overlap with those of plagioclase, consistent with plagioclase-breakdown and the low Sr concentrations in Population 4 titanite. Additionally, clinozoisite-epidote grains exhibit positive Eu anomalies. Allanite, which is observed in some clinozoisite-epidote cores, contains elevated $\mathrm{Th} / \mathrm{Pb}$ and LREE, and low U/Th relative to titanite. Therefore, the low $\mathrm{Sr}, \mathrm{Th} / \mathrm{Pb}$, and LREE, high U/Th, and deep negative Eu anomaly characteristic of Population 4 titanite may be entirely explained by exchange between titanite and epidote group minerals. Population 4 domains from both the plagioclase- and diopside-rich bands exhibit similar textures and compositions, suggesting a higher degree of trace element mobility at ca. 295 Ma. Garber et al. (2017) and Johnson, Cottle, \& Larson (2021) also observed titanite with low LREE and Sr in titanite from allanite-bearing rocks. Rims dated in sample SSP18-1A exhibit similar pooled date of $306 \pm 7 \mathrm{Ma}$ $(n=19, \mathrm{MSWD}=3.50)$. In both samples, titanite rims are elevated in $\mathrm{OH}, \mathrm{F}$, and $\mathrm{Al}$ (Fig. 3), consistent with a high $\mathrm{X}_{\mathrm{H} 2 \mathrm{O}}$ fluid (Garber et al., 2017). Ferry $(1976,2016)$ observed a late influx of $\mathrm{H}_{2} \mathrm{O}$-rich fluids in rocks $\sim 60 \mathrm{~km}$ northeast of our field area, suggesting potentially widespread metasomatism and retrograde metamorphism at ca. $295 \mathrm{Ma}$.

\subsection{Decoupling of titanite $\mathrm{U}-\mathrm{Pb}$ dates and trace element compositions}

Lead-loss, U-loss, and/or inheritance of unsupported radiogenic $\mathrm{Pb}$ can result in apparent ages that do not reflect the timing of metamorphism (e.g., Bonamici \& Blum, 2020; Castelli \& Rubatto, 2002; Garber et al., 2017; Kirkland et al., 2016; 2018; Smye et al., 2018). As a result, U$\mathrm{Pb}$ dates may decouple from major and trace element compositional zoning. Titanite from sample SSP18-1A exhibit no clear trends in texture, major and trace element concentrations, and date between ca. 380 and ca. 320 Ma (Fig. 6, 7b, \& 9). Additionally, titanite grains display equivalent dates between texturally overprinting zones, as well as significant age variation within some chemically homogenous zones (Figs. S4, S5). Plotted in a Tera-Wasserburg diagram, the analyses 
of grain interiors in sample SSP18-1A form a sub-horizontal array with a narrow range (0.08 to 0.10 ) in ${ }^{207} \mathrm{~Pb} /{ }^{206} \mathrm{~Pb}$ (Fig. 8b). In contrast, rim analyses of titanite in SSP18-1A, dated to $306 \pm 7$ $\mathrm{Ma}$, exhibit more restricted trace element concentrations and are similar in composition and age to Population 4 rim analyses in Sample SSP18-1B. Based on these observations, we suggest that titanite dates for interior zones from sample SSP18-1A do not reflect the timing of (re)crystallization.

The diffusion rate of $\mathrm{Pb}$ will differ from those of other trace elements with dissimilar size and charge; as a result, diffusive $\mathrm{Pb}$-loss may decouple dates from trace element zoning patterns. Although experimental diffusion rates for $\mathrm{Pb}$ in titanite suggest a $\mathrm{T}_{\mathrm{c}}$ of $600{ }^{\circ} \mathrm{C}$ (Cherniak, 1993), natural data suggest $\mathrm{Pb}$-loss by diffusion is unlikely to be efficient below $850{ }^{\circ} \mathrm{C}$ (Hartnady et al., 2019; Holder et al., 2019; Kohn, 2017; Stearns et al., 2016; Walters \& Kohn, 2017). Despite undergoing at least four metamorphic episodes, we observe no evidence of $\mathrm{Pb}$ diffusion in our samples. In SSP18-1B, core-to-rim variations in U-Pb date correspond closely to variations in texture and trace element chemistry, inconsistent with diffusive Pb-loss. Our dates for SSP18-1B also correlate well with known metamorphic and igneous events in the region, such as regional Acadian metamorphism at ca. $400 \mathrm{Ma}$ and Neoacadian metamorphism to the northwest at ca. 376 Ma (Sanislav, 2011; Smith \& Barreiro, 1990; Solar et al., 1998; Tomascak \& Solar, 2016). Leadloss cannot explain the different $\mathrm{U}-\mathrm{Pb}$ date-textural relationship between our two samples, which were collected from the same outcrop and experienced the same metamorphic histories. Additionally, the LA-ICP-MS Pb map of titanite from SSP18-1A reveals relatively sharp zoning (Fig., 9d). Our data are therefore consistent with the reevaluated $\mathrm{T}_{\mathrm{c}}$ for $\mathrm{Pb}$ in titanite.

Incorrect assumptions about the initial ${ }^{207} \mathrm{~Pb} /{ }^{206} \mathrm{~Pb}$ may also result in a decoupling of titanite $\mathrm{U}-\mathrm{Pb}$ dates from major and trace element patterns. Prograde, diagenetic, and detrital U-bearing phases, such as monazite, xenotime, allanite, and rutile, may break down during metamorphism (see discussions in Engi, 2017; Kohn, 2017) to release unsupported radiogenic $\mathrm{Pb}$ (e.g., Kirkland et al., 2018; Marsh \& Smye, 2017). As a result, the initial ${ }^{207} \mathrm{~Pb} /{ }^{206} \mathrm{~Pb}$ ratio of a metamorphic mineral will represent a mixture of 'common' unradiogenic $\mathrm{Pb}$ and unsupported radiogenic $\mathrm{Pb}$ (Bonamici \& Blum, 2020; Romer, 2001). Multiple analyses of one or more phases are commonly used to develop an isochron but assumes that each aliquot received the same initial ${ }^{207} \mathrm{~Pb} /{ }^{206} \mathrm{~Pb}$ ratio. Metamorphic titanite ${ }^{238} \mathrm{U} /{ }^{206} \mathrm{~Pb}$ and ${ }^{207} \mathrm{~Pb} /{ }^{206} \mathrm{~Pb}$ data often form linear arrays on TeraWasserburg diagrams, through which a linear regression constrains the initial ${ }^{207} \mathrm{~Pb} /{ }^{206} \mathrm{~Pb}$ ratio (e.g., Bonamici \& Blum, 2020; Marsh \& Smye, 2017; Kirkland et al., 2017, 2018). However, multiple linear arrays with different initial ${ }^{207} \mathrm{~Pb} /{ }^{206} \mathrm{~Pb}$ intercepts are sometimes observed, suggesting a variable contribution of unsupported radiogenic $\mathrm{Pb}$ (e.g., Bonamici \& Blum, 2020; Romer \& Rötzler, 2003). Correction of initial $\mathrm{Pb}$ by isochron is therefore only possible if linear arrays can be confidently discerned. Additionally, if radiogenic $\mathrm{Pb}$ released during the breakdown of U-bearing phases does not reach isotopic equilibrium with $\mathrm{Pb}$ in other phases then the ${ }^{207} \mathrm{~Pb} /{ }^{206} \mathrm{~Pb}$ ratio of low $\mathrm{U} / \mathrm{Pb}$ phases cannot be used to determine the initial ${ }^{207} \mathrm{~Pb} /{ }^{206} \mathrm{~Pb}$ ratio of titanite. Often the ${ }^{207} \mathrm{~Pb} /{ }^{206} \mathrm{~Pb}$ ratios measured on U-poor phases, such as plagioclase and alkali feldspar, fall within the value of initial ${ }^{207} \mathrm{~Pb} /{ }^{206} \mathrm{~Pb}$ defined by regression through titanite U- $\mathrm{Pb}$ data 


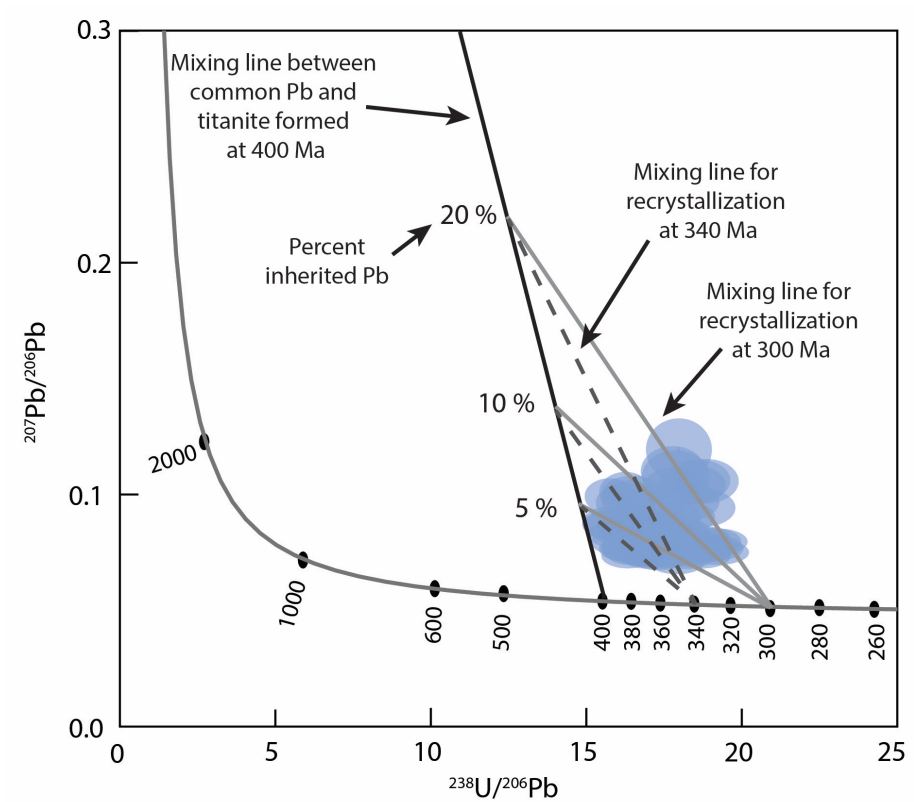

Figure 11. Tera-Wasserburg diagram showing error ellipses for titanite interior zones (excluding rims) from SSP18-1A (blue). A mixing line between titanite formed at $400 \mathrm{Ma}$ and a common $\mathrm{Pb}$ composition of 0.873 is shown in black. Mixing lines between the 400 Ma mixing line and theoretical titanite grains recrystallized at 340 (dark gray dashed lines) and $300 \mathrm{Ma}$ (light gray solid lines) significantly overlap with the measured $\mathrm{U}-\mathrm{Pb}$ data. Heterogeneous incorporation of $50 \%$ or less of unsupported radiogenic $\mathrm{Pb}$ from titanite crystallized at $400 \mathrm{Ma}$ during recrystallization at 340 or $300 \mathrm{Ma}$ would explain the narrow range of ${ }^{207} \mathrm{~Pb} /{ }^{206} \mathrm{~Pb}$ ratios and lack of a linear arrays in the titanite $\mathrm{U}-\mathrm{Pb}$ data.

(e.g., Johnson, Cottle, \& Larson, 2020; Kohn \& Corrie, 2011; Walters \& Kohn, 2017). For Sample SSP18-1B, we observe that isochrons for pooled dates at ca. 400 and ca. $295 \mathrm{Ma}$ (Pop. $1 \& 2$, respectively) demonstrate good agreement with the ${ }^{207} \mathrm{~Pb} /{ }^{206} \mathrm{~Pb}$ ratio measured on plagioclase (Fig. 8a). In contrast, U-Pb data from sample SSP18-1A form a cloud on the Tera-Wasserburg diagram

with a narrow ${ }^{207} \mathrm{~Pb} /{ }^{206} \mathrm{~Pb}$ ratio (Fig. $10 \mathrm{~b}$ ). No isochrons are discernable for analyses of grain interiors, consistent with a variably mixed initial ${ }^{207} \mathrm{~Pb} /{ }^{206} \mathrm{~Pb}$ ratio (Bonamici \& Blum, 2020).

We suggest that partial incorporation of unsupported radiogenic $\mathrm{Pb}$ during interface-coupled dissolutionreprecipitation (ICDR) reactions is responsible for the decoupling of titanite textures, compositions, and dates in Sample SSP18-1A. During ICDR, dissolution of the reactant phase produces a thin interfacial boundary layer of fluid that is supersaturated with respect to product phases, which nucleate at the reaction front (Putnis, 2009). Porosity is generated if the volume of reprecipitated solid matter is less than the volume dissolved, allowing the reaction front to propagate through the crystal if porosity is maintained (Ruiz-Agudo, Putnis, \& Putnis, 2014). Porosity is reduced at high temperatures by textural equilibration and, if the product phase is structurally similar to the reactant, crystallographic continuity may be preserved (Ruiz-Agudo, Putnis, \& Putnis, 2014).

Titanite grains from SSP18-1A exhibit cross-cutting, lobate, uneven, and fragmentary zones which are consistent with extensive ICDR (Figs. 3 \& 9; see review in Putnis, 2009). The lack of correlation between variations in titanite crystallographic orientation and chemical zoning is also consistent with ICDR (Figs. S7-S8). Lead liberated during titanite dissolution may be partially scavenged from the fluid before isotopic equilibrium is achieved with the bulk rock. For example, titanite formed at $400 \mathrm{Ma}$ with 5 to $20 \%$ common $\mathrm{Pb}$ may have recrystallized during subsequent metamorphic recrystallization at 340 or $300 \mathrm{Ma}$ (Fig. 11). The entire range of titanite $\mathrm{U}-\mathrm{Pb}$ ratios in SSP18-1A may be explained by $50 \%$ or less retainment of $\mathrm{Pb}$ during ICDR. Similar to our study, Castelli \& Rubatto (2002) found that the mixed-dates of complexly zoned 
metamorphic titanite from the Western Alps represented incomplete isotopic resetting during recrystallization. Inheritance of unsupported radiogenic $\mathrm{Pb}$ has also been observed in monazite. For example, Seydoux-Guillaume et al. (2003) observed a spread in monazite dates between initial growth at $2.5 \mathrm{Ga}$ and recrystallization at $790 \mathrm{Ma}$, which they attributed unsupported $\mathrm{Pb}$ in recrystallized domains. Weinberg et al. (2020) found that monazite dates, spread over 50 myr, were decoupled from chemical zonation and reflected inherited radiogenic $\mathrm{Pb}$ from older domains during ICDR reactions. When taken together with our study, these data suggest that dates of phases sensitive to ICDR, such as monazite and titanite, may lack geological meaning in polymetamorphic rocks and should be carefully screened prior to interpretation.

In contrast to SSP18-1A, titanite from SSP18-1B are dominated by regular core-to-rim zoning in composition and date that is consistent with titanite crystallization (Castelli \& Rubatto, 2002). We suggest that neocrystallization and secondary growth of titanite, which requires reactions with low $\mathrm{U} / \mathrm{Pb}$ major mineral phases to liberate $\mathrm{Ca}, \mathrm{Ti}, \mathrm{Al}$, and $\mathrm{Si}$, will form titanite with an initial $\mathrm{Pb}$ composition dominated by common $\mathrm{Pb}$. In contrast, recrystallization of titanite by ICDR may limit isotopic homogenization of $\mathrm{Pb}$. Additionally, the larger grain size and higher modal abundance of titanite in SSP18-1A $(\leq 2.5 \mathrm{~mm}, \sim 10 \mathrm{vol} \%)$ relative to SSP18-1B $(<800$ $\mu \mathrm{m}, 1-2 \mathrm{vol} \%$ ), suggests that a greater percentage of the bulk rock Pb budget is stored in titanite in SSP18-1A. These differences may have also played a role in the availability of radiogenic $\mathrm{Pb}$ relative to common $\mathrm{Pb}$ during titanite ICDR reactions.

\subsection{Common Pb uptake during crystallization}

Titanite may incorporate significant common $\mathrm{Pb}$ upon crystallization (e.g., Bonamici \& Blum, 2020; Kirkland et al., 2018; Kohn, 2017). High ratios of common to radiogenic $\mathrm{Pb}$ require large extrapolations to concordia and result in $\mathrm{U}-\mathrm{Pb}$ dates with high uncertainties. The initial $\mathrm{U} / \mathrm{Pb}$ ratio inherited by titanite will be a function of the bulk rock $\mathrm{U} / \mathrm{Pb}$ ratio and the relative partitioning of these phases between minerals during continuous and discontinuous metamorphic reactions (Römer, 2001).

Titanite in both our samples display less than $20 \%$ inherited common ${ }^{207} \mathrm{~Pb} /{ }^{206} \mathrm{~Pb}(f 207)$ (e.g., Kirkland et al., 2016; 2018). In Figure 12, we plot $f 207$ of titanite analyses from SSP18-1B as a function of date and Sr concentration. A decrease in $f 207$ is observed between ca. 400 and ca. $372 \mathrm{Ma}$ followed by an increase from ca. 342 to ca. $295 \mathrm{Ma}$ (Fig. 12a). Strontium concentrations in titanite are positively correlated with $f 207$ at ca. $400 \mathrm{Ma}$, uncorrelated at ca. $372 \mathrm{Ma}$, and negatively correlated at ca. $295 \mathrm{Ma}$ (Fig. 12b). Plagioclase in SSP18-1B contains 20.5-23.9 $\mu \mathrm{g} \mathrm{g}^{-}$

${ }^{1} \mathrm{~Pb}$, compared to $1.55-28.8 \mu \mathrm{g} \mathrm{g}{ }^{-1}$ measured in titanite (radiogenic + inherited $\mathrm{Pb}$, Table S2 \& S7). Plagioclase is considerably more abundant (up to $\sim 80 \mathrm{vol} \%$ in plagioclase-rich bands) than titanite (1-2 vol \%) and is therefore the largest $\mathrm{Pb}$ sink in SSP18-1B. The initial decease in $f 207$ and $\mathrm{Sr}$ corresponds to an increase in plagioclase modes between ca. 400 and ca. $372 \mathrm{Ma}$, whereas the elevated $f 207$ at ca. $295 \mathrm{Ma}$ corresponds to plagioclase breakdown (Fig. 10b \& 12). We suggest that the presence of phases that fractionate $\mathrm{Pb}$ from $\mathrm{U}$, such as An-rich plagioclase and alkali 


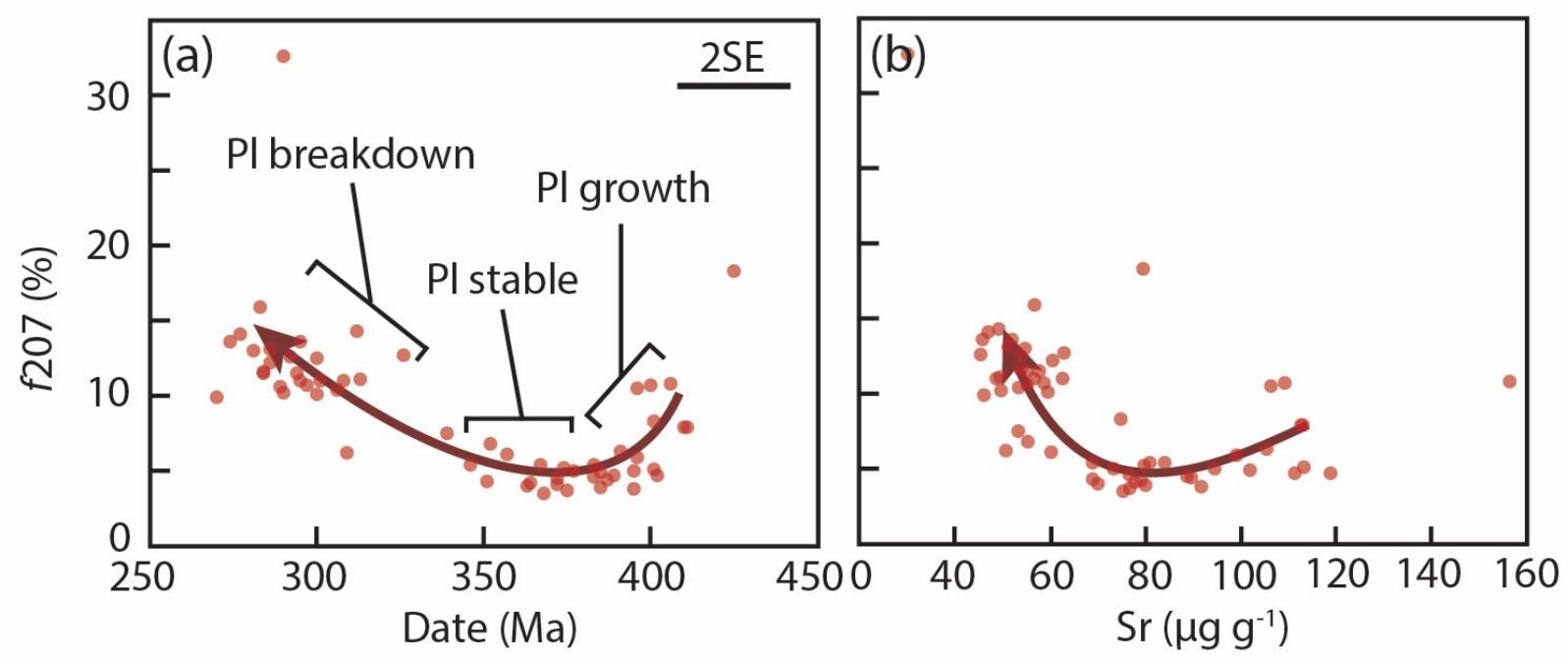

Figure 12. Percent of common $\mathrm{Pb}(f 207)$ in titanite plotted relative to (a) date and (b) Sr concentration. The average 2SE uncertainty of single spot dates (black scale bar) and trends with time (red arrow) are shown. In (a), plagioclase shows a trend of decreasing $f 207$ attributed to plagioclase growth, followed by an increase in $f 207$ corresponding to hydration, An-rich plagioclase breakdown, and the formation of epidote group minerals. In (b), Sr concentrations roughly mirror the trend with date, showing correlation between $f 207$ and Sr during the early and final stages of metamorphism.

feldspar, is a key factor contributing to low common $\mathrm{Pb}$ and may lead to both more precise and accurate titanite $\mathrm{U}-\mathrm{Pb}$ ages.

\section{4 $P-T$ conditions of retrogression and $\mathrm{Zr}$-in-titanite disequilibrium}

Population 4 titanite rim domains dated to ca. $295 \mathrm{Ma}$ in sample SSP18-1B give Zr-intitanite temperatures of $\sim 750{ }^{\circ} \mathrm{C}$. Titanite rims are associated with the retrograde assemblage amphibole, clinozoisite/epidote, allanite, albitic plagioclase, and quartz. The presence of zircon and retrograde quartz suggests that assumptions of unity for $a_{\mathrm{ZrSiO} 4}$ and $a_{\mathrm{SiO} 2}$ are reasonable for Population $4 \mathrm{Zr}$-in-titanite temperatures. The $T$ estimate of $750{ }^{\circ} \mathrm{C}$ is inconsistent with the retrograde assemblage in the calcsilicates. The reaction of diopside and anorthite to quartz, clinozoisite, and tremolite (Reaction 9) observed in SSP18-1B is expected to occur at $\leq 550{ }^{\circ} \mathrm{C}$ at $500 \mathrm{MPa}$ (Fig. 10a). Additionally, attempts to calculate pressures using the titanite, clinozoisite, anorthite, rutile, quartz (TZARS) barometer of Kapp, Manning, \& Tropper (2009) at $750{ }^{\circ} \mathrm{C}$ produced unrealistically high pressures of $>1.0 \mathrm{GPa}$, whereas more reasonable pressures of 600 $\mathrm{MPa}$ were calculated for $500{ }^{\circ} \mathrm{C}$.

The Zr-in-titanite temperatures are also inconsistent with retrograde assemblages of metapelite and metapsammite rocks from the sampled outcrop. At $500 \mathrm{MPa}$, vapor-present muscovite-dehydration melting occurs at temperatures above $\sim 650{ }^{\circ} \mathrm{C}$ (Fig. S11). Sillimanite is observed in garnet inclusions in metapelite sample SSP18-1D and no sillimanite is observed in the matrix, in contrast muscovite is abundant in the matrix but absent from inclusions. Rehydration of metapelites below the wet-solidus will produce muscovite at the expense of sillimanite (the reverse of the muscovite-dehydration reaction). Prehnite is observed to replace biotite in metapsammitic 
bands in Sample SSP18-1A. These require relatively low $T$ retrogression and hydration of the metapelite and metapsammite rocks and suggest a shared history of fluid infiltration with the calcsilicate bands at ca. 295 Ma. Johnson, Cottle, \& Larson (2020) suggested limited equilibrium between titanite and zircon in their samples resulted in Zr-in-titanite temperatures that are 100 to $150{ }^{\circ} \mathrm{C}$ higher than temperatures calculated from other techniques and inconsistent with the observed mineral assemblages. Here we also suggest that quartz and/or zircon cannot be in equilibrium with titanite at ca. $295 \mathrm{Ma}$ and suggest caution when applying the Zr-in-titanite thermometer (e.g., Cruz-Uribe et al., 2018).

\subsection{Implications for the tectono-metamorphic history of western Maine}

The Acadian Orogeny (420 to $350 \mathrm{Ma}$ ) is the dominant tectono-metamorphic event in the northern Appalachian Mountains and corresponds to the collision of the Avalon terrane with the eastern margin of Laurentia (Robinson et al., 1998; van Staal et al., 2009). Based on stratigraphic constraints and intrusion ages, Bradley et al. (2000) suggested that the Acadian deformation front moved from coastal Maine into Québec between at 423 and 382.5 Ma. The northwestward migration of the deformation front is consistent with ca. $400 \mathrm{Ma}$ zircon and monazite ages observed throughout west-central Maine and New Hampshire (Gerbi \& West, 2007; Pyle et al., 2005; Moecher, McCulla, \& Massey, 2020; Smith \& Barreiro, 1990; Solar et al., 1998; Wing, Ferry, \& Harrison, 2003). The pooled Population 1 titanite date of ca. $400 \mathrm{Ma}$ therefore corresponds to widespread regional Acadian metamorphism.

Studies of metamorphism in western Maine have long proposed that metamorphism in western Maine during the Neoacadian (380-350 Ma) and Alleghenian (325-260) Ma orogenies (Robinson et al., 1998) was driven by pluton emplacement and contact heating, resulting in localized overprinting cycles of low-P prograde and retrograde metamorphism (see review in Guidotti, 1989). The increase in $\mathrm{X}_{\mathrm{Di}}$ between recrystallized and fractured diopside, breakdown of residual amphibole ( \pm biotite), and higher maximum $\mathrm{Zr}$-in-titanite $T$ indicate that the highest thermal conditions experienced by our samples occurred at ca. $372 \mathrm{Ma}$ (Fig. 10). These data, in conjunction with the pooled ca. $376 \mathrm{Ma}$ age of zircons from migmatites to the west of our field area (Tomascak \& Solar, 2016), suggest that anatexis and deformation in this region occurred 20$30 \mathrm{Ma}$ later than in the migmatites in the vicinity of the Mooselookmeguntic pluton (Fig. 1a) (Brown \& Solar, 1999; Johnson, Brown, \& Solar, 2003). Partial melting ceased prior to ca. 295 Ma, suggesting no connection between anatexis and the emplacement of the Sebago pluton. Instead, high- $T$ metamorphism at ca. $372 \mathrm{Ma}$ overlaps with the 380-330 Ma period of partial melting observed in New Hampshire, central Massachusetts, and central Connecticut (see compilation in Hillenbrand et al., 2021). Retrograde metamorphism at ca. $295 \mathrm{Ma}$ corresponds to the age of the Sebago pluton (Tomascak, Krogstad, \& Walker, 1996), which may have been the source of the high $\mathrm{X}_{\mathrm{H} 2 \mathrm{O}}$ fluids.

Neoacadian and Alleghenian metamorphism in western Maine is thought largely to be postdeformational, following localization of deformation to the Norumbega Fault System by ca. 380 Ma (Hubbard et al., 1995; Gerbi \& West, 2007; Ludman, 1998; West \& Hubbard, 1997; West, 
1999). Metapelitic rocks in our field area exhibit stretched leucosomes that are oriented parallel to boudinaged dikes (Fig. S1a-b), which require that anatexis and dike emplacement was either preor syn-tectonic. A second generation of dikes is also observed, but these are undeformed and crosscut the foliation of the host gneisses (Fig. S1c-d). Based on these relationships, we also suggest that deformation in west-central Maine continued even after the initiation of dextral shear on the Norumbega Fault System, requiring that at least some strain was partitioned further inland.

\section{CONCLUSIONS}

Titanite is a highly reactive mineral that may record multiple generations of crystallization, growth, and dissolution-reprecipitation. In addition, the temperature-dependent incorporation of $\mathrm{Zr}$ and the slow diffusivity of $\mathrm{Pb}$ make titanite a potentially excellent petrochronometer. However, titanite may incorporate significant initial $\mathrm{Pb}$, potentially resulting in inaccurate age determination. Here we demonstrate both the benefits and shortcomings of titanite chronometry. Our data for sample SSP18-1B reveals four phases of metamorphism spanning a period from ca. 400 to ca. 295 Ma. Most titanite grains in this sample exhibit systematic core-to-rim variations in trace element concentrations and $\mathrm{U}-\mathrm{Pb}$ dates, consistent with neocrystallization and secondary overgrowth. Trace element concentrations and REE patterns reflect changing partitioning between titanite and other phases, revealing the breakdown of hydrous phases between ca. 400 and ca. 342 followed by an influx of hydrous fluids at ca. $295 \mathrm{Ma}$. Metamorphism at ca. $400 \mathrm{Ma}$ corresponds to the northwestward migration of the Acadian front, whereas the highest temperature conditions correspond a period of metamorphism at ca. $372 \mathrm{Ma}$ and are consistent with wide-spread partial melting observed throughout greater New England. Retrogression at ca. $295 \mathrm{Ma}$ may be related to hydrous fluids exsolved from the crystallizing Sebago pluton to the SW of our field area. In contrast, titanite from a second sample (SSP18-1A) exhibits little correlation between trace element concentrations, REE patterns, texture, and date. We suggest date-composition decoupling is caused by the incorporation of variable amounts of unsupported radiogenic $\mathrm{Pb}$ in recrystallized domains, resulting in mixed geologically-meaningless ages. We suggest that titanite may reliably record multiple phases of metamorphism; however, $\mathrm{U}-\mathrm{Pb}$ dates should be coupled with chemical and textural characterization to screen for unsupported radiogenic $\mathrm{Pb}$ in recrystallized domains.

\section{ACKNOWLEDGEMENTS}

We thank M. Yates for assistance with EPMA analyses, and H.L. Brooks and J. Stone for assistance with LA-ICP-MS analyses. Additionally, we thank J. Garber, M.J. Kohn, H. Marschall, W. Müller, and M. Konrad-Schmolke for fruitful discussions of these data. J. Ferry is thanked for suggesting calcsilicate sampling locations in Maine. JBW acknowledges Fulbright and Chase Distinguished Research Fellowships.

\section{REFERENCES}

Aleinikoff, J.N., Wintsch, R.P., Tollo, R.P., Unruh, D.M., Fanning, C.J., \& Schmitz, M.D. (2007). Ages and origins of rocks of the Killingworth dome, south-central Connecticut: 
Implications for the tectonic evolution of southern New England. American Journal of Science, 307, 63-118.

Behn, M.D., Eusden, J.D., \& Notte, II, J.A. (1998). A three-dimensional gravity model of the southern contact of the Sebago pluton, Maine. Canadian Journal of Earth Sciences, 35, $649-656$.

Berman, R.G. (1990). Mixing properties of Ca-Mg-Fe-Mn garnets. American Mineralogist, 75, 328-344.

Bonamici, C.E., Fanning, C.M., Kozdon, R., Fournelle, J.H., \& Valley, J.W. (2015). Combined oxygen-isotope and $\mathrm{U}-\mathrm{Pb}$ zoning studies of titanite: New criteria for age preservation. Chemical Geology, 398, 70-84.

Bradley, D.C., Tucker, R.D., Lux, D.R., Harris, A.G., \& McGregor, C. (2000). Migration of the Acadian orogen and foreland basin across the northern Appalachians of Maine and adjacent areas. U.S. Geological Survey Professional Paper, 1624, 1-45.

Brown, M., \& Solar, G.S. (1999). The mechanism of ascent and emplacement of granite magma during transpression: A syntectonic granite paradigm. Tectonophysics, 312, 1-33.

Chambers, J.A., \& Kohn, M.J. (2012). Titanium in muscovite, biotite, and hornblende: Modeling, thermometry, and rutile activities of metapelites and amphibolites. American Mineralogist, $97,543-555$.

Castelli, D., \& Rubatto, D. (2002). Stability of Al- and F-rich titanite in metacarbonate: Petrologic and isotopic constraints from a polymetamorphic eclogite marble of the internal Sesia Zone (Western Alps). Contributions to Mineralogy and Petrology, 142, 627-639.

Cherniak, D.J. (1993). Lead diffusion in titanite and preliminary results on the effects of radiation damage on Pb transport. Chemical Geology, 110, 177-194.

Connolly, J.A.D. (2005). Computation of phase equilibria by linear programming: A tool for geodynamic modelling and its application to subduction zone decarbonation. Earth and Planetary Science Letters, 236, 524-541.

Corfu, F. (1996). Multistage zircon and titanite growth and inheritance in an Archean gneiss complex, Winnipeg River Subprovince, Ontario. Earth and Planetary Science Letters, 141, $175-186$.

Cruz-Uribe, A.M., Feineman, M.D., Zack, T., \& Jacob, D.E. (2018). Assessing trace element (dis)equilibrium and the application of single element thermometers in metamorphic rocks. Lithos, 314-315, 1-15.

Engi, M. (2017). Petrochronology based on REE-minerals: Monazite, allanite, xenotime, apatite. Reviews in Mineralogy and Geochemistry, 83, 365-418. 
Ferry, J.M. (1976). Metamorphism of calcareous sediments in the Waterville-Vassalboro area, south-central Maine: Mineral reactions and graphical analysis. American Journal of Science, 276, 841-882.

Ferry, J.M. (2016). Fluids in the crust during regional metamorphism: Forty years in the Waterville limestone. American Mineralogist, 101, 500-517.

Ferry, J.M., \& Spear, F.S. (1978). Experimental calibration of the partitioning of Fe and $\mathrm{Mg}$ between biotite and garnet. Contributions to Mineralogy and Petrology, 66, 113-117.

Frei, D., Liebscher, A., Franz, G., \& Dulski, P. (2004). Trace element geochemistry of epidote minerals. Reviews in Mineralogy and Geochemistry, 56, 553-605.

Frost, B.R., Chamberlain, K.R., \& Schumacher, J.C. (2000). Sphene (titanite): Phase relations and role as a geochronometer. Chemical Geology, 172, 131-148.

Garber, J.M., Hacker, B.R., Kylander-Clark, A.R.C., Stearns, M., \& Seward, G. (2017). Controls on trace element uptake in metamorphic titanite: Implications for petrochronology. Journal of Petrology, 58, 1031-1057.

Gerbi, C., \& West, D.P., Jr. (2007). Use of U-Pb geochronology to identify successive, spatially overlapping tectonic episodes during Silurian-Devonian orogenesis in south-central Maine, USA. Geological Society of America Bulletin, 119, 1218-1231.

Ghent, E.D., \& Stout, M.Z. (1984). TiO2 activity in metamorphosed pelitic and basic rocks: Principles and applications to metamorphism in southeastern Canadian Cordillera. Contributions to Mineralogy and Petrology, 86, 248-255.

Gordon, S.M., Kirkland, C.L., Reddy, S.M., Blatchford, H.J., Whitney, D.L., Teyssier, C., ... McDonald, B.J. (2021). Deformation-enhanced recrystallization of titanite drives decoupling between U-Pb and trace elements. Earth and Planetary Science Letters, 560, 116810.

Groppo, C., Rolfo, F., Castelli, D., \& Mosca, P. (2017). Metamorphic CO2 production in collisional orogens: Petrological constraints from phase diagram modeling of Himalayan, scapolite-bearing, calc-silicate rocks in the $\mathrm{NKC}(\mathrm{F}) \mathrm{MASH}(\mathrm{T})-\mathrm{HC}$ system. Journal of Petrology, 58, 53-83.

Guidotti, C.V. (1970). The mineralogy and petrology of the transition from lower to upper sillimanite zone in the Oquossoc area, Maine. Journal of Petrology, 11, 277-336.

Guidotti, C.V. (1989). Metamorphism in Maine: An overview. In R.D. Tucker, \& R.G. Marvinney (Eds.), Studies in Maine geology, Maine Geological Survey, 3, 1-19. 
Hartnady, M.I.H., Kirkland, C.L., Clark, C., Spaggiari, C.V., Smithies, R.H., Evans, N.J., \& McDonald, B.J. (2019). Titanite dates crystallization: Slow Pb diffusion during supersolidus re-equilibration. Journal of Metamorphic Petrology, 37, 823-838.

Hawthorne, F.C., Groat, L.A., Raudsepp, M., Ball, N.A., Kimata, M., Spike, F.D., ... McCammon, C. (1991). Alpha-decay damage in titanite. American Mineralogist, 76, 370-396.

Hawthorne, F.C., Oberti, R., Harlow, G.E., Maresch, W.V., Martin, R.F., Schumacher, J.C., \& Welch, M.D (2012). Nomenclature of the amphibole supergroup. American Mineralogist, 97, 2031-2048.

Hayden, L.A., Watson, E.B., Wark, D.A. (2008). A thermobarometer for sphene (titanite). Contributions to Mineralogy and Petrology, 155, 529-540.

Hillenbrand, I.W., Williams, M.L., Li, C., \& Gao. H. (2021). Rise and fall of the Acadian altiplano: Evidence for a Paleozoic orogenic plateau in New England. Earth and Planetary Science Letters, 560, 116797.

Hibbard, J.P., van Staal, C.R., Rankin, D., \& Williams, H. (2006). Lithotectonic map of the Appalachian orogen (North), Canada-United States of America. Geological Survey of Canada, 02041A.

Hodges, K.V., \& Crowley, P.D. (1985). Error estimation and empirical geothermobarometry for pelitic systems. American Mineralogist, 70, 702-709.

Holdaway, M.J, Dutrow, B.L., \& Hinton, R.W. (1988). Devonian and Carboniferous metamorphism in west-central Maine: The muscovite-almandine geobarometer and the staurolite problem revisited. American Mineralogist, 73, 20-47.

Holdaway, M.J., Mukhapodhyay, B., Dyar, M.D., Guidotti, C.V., \& Dutrow, B.L. (1997). Garnetbiotite geothermometry revised: New Margules parameters and a natural specimen data set from Maine. American Mineralogist, 82, 582-595.

Holder, R.M., \& Hacker, B.R. (2019). Fluid-driven resetting of titanite following ultrahightemperature metamorphism in southern Madagascar. Chemical Geology, 504, 38-52.

Holder, R.M., Hacker, B.R., Seward, G.G.E., \& Kylander-Clark, A.R.C. (2019). Interpreting titanite $\mathrm{U}-\mathrm{Pb}$ dates and $\mathrm{Zr}$ thermobarometry in high-grade rocks: Empirical constraints on elemental diffusivities of $\mathrm{Pb}, \mathrm{Al}, \mathrm{Fe}, \mathrm{Zr}, \mathrm{Nb}$, and $\mathrm{Ce}$. Contributions to Mineralogy and Petrology, 174, 1-19.

Hubbard, M.S., West, D.P., Jr., Ludman, A., Guidotti, C.V., \& Lux, D.R. (1995). The Norumbega fault zone, Maine: A mid- to shallow-level crustal section within a transcurrent shear zone. Atlantic Geology, 31, 109-116. 
Hussey, A.M. (1983). Bedrock geology of the Lewiston 15-minute quadrangle, Maine. Maine Geological Survey Open-File Report, OF-83-4.

Jochum, K.P., Weis, U., Stoll, B., Kuzmin, D., Yang, Q. Raczek, I., ... Enzwiler, J. (2011). Determination of reference values for NIST SRM 610-617 glasses following ISO guidelines. Geostandardards and Geoanalytical Research, 35, 397-429.

Johnson, T.E., Brown, M., \& Solar, G.S. (2003). Low-pressure subsolidus and suprasolidus phase equilibria in the MnNCKFMASH system: Constraints on conditions of regional metamorphism in western Maine, northern Appalachians. American Mineralogist, 88, 624638.

Johnson, T.A., Cottle, J.M., \& Larson, K.P. (2020). Delineation of multiple metamorphic events in the Himalayan Kathmandu Complex, central Nepal. Journal of Metamorphic Geology, 00, 1-30.

Kapp, P., Manning, C.E., \& Tropper, P. (2009). Phase-equilibrium constraints on titanite and rutile activities in mafic epidote amphibolites and geobarometry using titanite-rutile equilibria. Journal of Metamorphic Geology, 27, 509-521.

Kirkland, C.L., Spaggiari, C.V., Johnson, T.E., Smithies, R.H., Danišík, M., Evans, N., ... McDonald, B.J. (2016). Grain size matters: Implications for element and isotopic mobility in titanite. Precambrian Research, 278, 283-302.

Kirkland, C.L., Hollis, J., Danišik, M., Petersen, J., Evans, N.J., McDonald, B.J. (2017). Apatite and titanite from the Karrat Group, Greenland: Implications for charting the thermal evolution of crust from the U-Pb geochronology of common $\mathrm{Pb}$ bearing phases. Precambrian Research, 300, 107-120.

Kirkland, C.L., Fougerouse, D., Reddy, S.M., Hollis, J., Saxey D.W. (2018). Assessing the mechanisms of common $\mathrm{Pb}$ incorporation into titanite. Chemical Geology, 483, 558-566.

Kohn, M.J. (2017). Titanite petrochronology. Reviews in Mineralogy \& Geochemistry, 83, 419441.

Kohn, M.J., \& Corrie, S.L. (2011). Preserved Zr-temperatures and U-Pb ages in high-grade metamorphic titanite: Evidence for a static hot channel in the Himalayan orogen. Earth and Planetary Science Letters, 311, 136-143.

Konrad-Schmolke, M., Halama, R., Wirth, R., Thomen, A., Klitscher, N., Morales, L., ... Wilke, F.D.H. (2018). Mineral dissolution and reprecipitation mediate by an amorphous phase. Nature Communicationns, 9, 1637.

Lanari, P., Vidal, O., de Andrade, V., Dubacq, B., Lewin, E., Grosch, E.G., Schwartz, S. (2014). XMapTools: A MATLABC-based program for electron microprobe X-ray image processing and geothermobarometry. Computers \& Geosciences, 62, 227-240. 
Lanari, P., Vho, A., Bovay, T., Airaghi, L., Centrella, S. (2018). Quantitative compositional mapping of mineral phases by electron probe micro-analyser. Geological Society of London, Special Publications, 478, 39-63.

Leake, B.E., Woolley, A.R., Arps, C.E.S., Birch, W.D., Gilbert, M.C., Grice, J.L., ... Youzhi, G. (1997). Nomenclature of Amphiboles: Report on the subcommittee on amphiboles of the International Mineralogical Association, Commission on New Minerals and Mineral Names. American Mineralogist, 82, 1019-1037.

Ludman, A. (1998). Evolution of a transcurrent fault system in shallow crustal metasedimentary rocks: The Norumbega fault zone, eastern Maine. Journal of Structural Geology, 20, 93107.

Ludwig, K.R. (1988). ISOPLOT for MS-DOS, a plotting and regression program for radiogenic isotope data for IBM-PC compatible computers, Version 1.00. US Geological Survey Open-File Report, OF-88-0557.

Lux, D.R., \& Guidotti, C.V. (1985). Evidence for extensive Hercynian metamorphism in western Maine. Geology, 13, 695-700.

Marsh, J.H., \& Smye, A.J. (2017). U-Pb systematics and trace element characteristics in titanite from a high-pressure mafic granulite. Chemical Geology, 466, 403-416.

Mattinson, J.M. (1978). Age, origin, and thermal histories of some plutonic rocks from the Salinian block of California. Contributions to Mineralogy and Petrology, 67, 233-245.

Mazdab, F.K. (2009). Characterization of flux-grown trace-element-doped titanite using highmass-resolution ion microprobe (SHRIMP-RG). Canadian Mineralogist, 47, 813-831.

Mezger, K., Rawnsley, C.M., Bohlen, S.R., \& Hanson, G.N. (1991). U-Pb garnet, sphene, monazite, and rutile ages: Implications for the duration of high-grade metamorphism and cooling histories, Adirondack Mts, New York. Journal of Geology, 99, 415-428.

Moecher, D.P., McCulla, J.K., \& Massey, M.A. (2020). Zircon and monazite geochronology in the Palmer zone of transpression, south-central New England, USA: Constraints on timing of deformation, high-grade metamorphism, and lithospheric foundering during late Paleoxoic oblique collision in the northern Appalachian orogen. GSA Bulletin. https:// doi/10.1130/B35744.1

Papapavlou, K., Darling, J.R., Moser, D.E., Barker, I.R., EIMF, White, L.F., ... Dunlop, J. (2018). $\mathrm{U}-\mathrm{Pb}$ isotopic dating of titanite microstructures: Potential implications for the chronology and identification of large impact structures. Contributions to Mineralogy and Petrology, $173,1-15$. 
Paton, C., Hellstrom, J., Paul., B., Woodhead, J., \& Hergt, J. (2011). Iolite: Freeware for the visualization and processing of mass spectrometric data. Journal of Analytical Spectrometry, 26, 2508.

Paul, B., Paton, C., Norris, A., Woodhead, J., Hellstrom, J., Hergt, J., \& Greig, A. (2012). Cell space: A Module for creating spatially registered laser ablation images within the Iolite freeware environment. Journal of Analytical and Atomic Spectrometry, 27, 700-706.

Pearce, N.J.G., Perkins, W.T., Westgate, J.A., Gorton, M.P., Jackson, S.E., Neal, C.R., \& Chenery, S.P. (1997). A compilation of new and published major and trace element data for NIST SRM 610 and NIST SRM 612 glass reference materials. Geostandards Newsletter, 21, 115-144.

Putnis, A (2009). Mineral replacement reactions. Reviews in Mineralogy and Geochemistry, 70, 87-124.

Pyle, J.M., Spear, F.S., Cheney, J.T., \& Layne, G. (2005). Monazite ages in the Chesham Pond Nappe, SW New Hampshire, U.S.A.: Implications for assembly of central New England thrust sheets. American Mineralogist, 90, 592-606.

Rankin, D.W., Coish, R.A., Tucker, R.D., Peng, Z.X., Wilson, S.A., \& Rouff, A.A. (2007). Silurian extension in the Upper Connecticut Valley, United States and the origin of Middle Paleozoic basins in the Québec embayment. American Journal of Science, 307, 216-264.

Raimondo, T., Payne, J., Wade, B., Lanari, P., Clark, C., \& Hand, M. (2017). Trace element mapping by LA-ICP-MS: Assessing geochemical mobility in garnet. Contributions to Mineralogy and Petrology, 172, 1-22.

Rapa, G., Groppo, C., Rolfo, F., Petrelli, M., Mosca, P., \& Perugini, D. (2017). Titanite-bearing calc-silicate rocks constrain timing, duration and magnitude of metamorphic $\mathrm{CO} 2$ degassing in the Himalayan belt. Lithos, 292-293, 364-378.

Robinson, P., Tucker, R.D., Bradley, D., Berry, H.N., \& Osberg, P.H. (1998). Paleozoic orogens in New England, USA. GFF, 120, 119-148.

Romer, R.L. (2001). Lead incorporation during crystal growth and the misinterpretation of geochronological data from low-238U/204Pb metamorphic minerals. Terra Nova, 13, 258263.

Romer, R.L., \& Rotzler, J. (2003). Effect of metamorphic reaction history on the U-Pb dating of titanite. Geological Society of London, Special Publications, 220, 147-158.

Ruiz-Agudo, E., Putnis, C.V., \& Putnis, A. (2014). Coupled dissolution and precipitation at mineral-fluid interfaces. Chemical Geology, 383, 132-146. 
Sanislav, I.V. (2011). A long-lived metamorphic history in the contact aureole of the Mooselookmeguntic pluton revealed by in situ dating of monazite grains preserved as inclusions in staurolite porphyroblasts. Journal of Metamorphic Geology, 29, 251-273.

Seydoux-Guillaume, A.M., Goncalves, P., Wirth, R., \& Deutsch, A (2003). Transmission electron microscope study of polyphase and discordant monazites: Site-specific specimen preparation using the focused ion beam technique. Geology, 31, 973-976.

Schoene, B., \& Bowring, S.A. (2006). U-Pb systematics of the McClure Mountain syenite: Thermochronological constraints on the age of the 40Ar/39Ar standard MMhb. Contributions to Mineralogy and Petrology, 151, 615-630.

Scott, D.J., \& St-Onge, M.R. (1995). Constraints on Pb closure temperature in titanite based on rocks from the Ungava orogen, Canada: Implications for U-Pb geochronology and PTt path determinations. Geology, 23, 1123-1126.

Schumacher, J. (1991). Empirical ferric iron corrections: Necessity, assumptions, and effects on selected geothermobarometers. Mineralogical Magazine, 55, 3-18.

Smith, H.A., \& Barreiro, B. (1990). Monazite U-Pb dating of staurolite grade metamorphism in pelitic schists. Contributions to Mineralogy and Petrology, 105, 602-615.

Smye, A.J., Marsh, J.H., Vermeesch, P., Garber, J.M., \& Stockli, D.F. (2018). Applications and limitations of $\mathrm{U}-\mathrm{Pb}$ thermochronology to middle and lower crustal thermal histories. Chemical Geology, 494, 1-18.

Solar, G.S., Pressley, R.A., Brown, M., \& Tucker, R.D. (1998). Granite ascent in convergent orogenic belts: Testing a model. Geology, 26, 711-714.

Solar, G.S., \& Brown, M. (1999). The classic high-T - Low-P metamorphism of west-central Maine: Is it Post-tectonic or syntectonic? Evidence from porphyroblast-matrix relations. Canadian Mineralogist, 37, 311-333.

Solar, G.S., \& Tomascak, P.B. (2016). The migmatite-granite complex of southern Maine: Its structure, petrology, geochemistry, geochronology, and relation to the Sebago Pluton. In H.N. Berry, \& D.P. West Jr. (Eds.), Guidebook for field trips along the Maine coast from Maquoit Bay to Muscongus Bay. 2016 New England Intercollegiate Geological Conference, 19-42.

Spandler, C., Hammerli, J., Sha, P., Hilbert-Wolft, H., Hu, Y., Roberts, E., \& Schmitz, M. (2016). MKED1: A new titanite standard for in situ analyses of Sm-Nd isotopes and U-Pb geochronology. Chemical Geology, 425, 110-126.

Spear, F.S., \& Parish, R.R. (1996). Petrology and cooling rates of the Valhalla Complex, British Columbia, Canada. Journal of Petrology, 37, 733-765. 
Spencer, K.J., Hacker, B.R., Kylander-Clark, A.R.C., Andersen, T.B., Cottle, J.M., Stearns, M.A., ... Seward, G.G.E. (2013). Campaign-style titanite U-Pb dating by laser-ablation ICP: Implications for crustal flow, phase transformations and titanite closure. Chemical Geology, 341, 84-101.

Stacey, J.S., \& Kramers, J.D. (1975). Approximation of terrestrial lead isotope evolution by a twostage model. Earth and Planetary Science Letters, 26, 207-221.

Stearns, M.A., Cottle, J.M., Hacker, B.R., \& Kylander-Clark, A.R.C. (2016). Extracting thermal histories from the near-rim zoning in titanite using coupled $\mathrm{U}-\mathrm{Pb}$ and trace element depth profiles by single-shot laser-ablation split stream (SS-LASS) ICP-MS. Chemical Geology, 422, 13-24.

Stearns, M.A., Hacker, B.R., Ratschbacher, L., Rutte, D., \& Kylander-Clark, A.R.C. (2015). Titanite petrochronology of the Pamir gneiss domes: Implications for mid-deep crust exhumation and titanite closure to $\mathrm{Pb}$ and $\mathrm{Zr}$ diffusion. Tectonics, 34, 1-19.

Sun, S.S., \& McDonough, W.F. (1989). Chemical and isotopic systematics of oceanic basalts: Implications for mantle composition and processes. Geological Society of London, Special Publications, 42, 313-345.

Thomas, J.B., Watson, E.B., Spear, F.S., Shemella, P.T., Nayak, S.K., \& Lanzirotti, A. (2010). TitaniQ under pressure: The effect of pressure and temperature on the solubility of Ti in quartz. Contributions to Mineralogy and Petrology, 160, 743-759.

Thomson, J.A., \& Guidotti, C.V. (1989). Carboniferous Barrovian metamorphism in southern Maine. Studies in Maine Geology, 3, 35-51.

Tomascak, P.B., Krogstad, E.J., \& Walker, R.J. (1996). U-Pb monazite geochronology of granitic rocks from Maine: Implications for Late Paleozoic tectonics in the northern Appalachians. Journal of Geology, 104, 185-195.

Tomascak, P.B., \& Solar, G.S. (2016). Anatomy of the migmatite-granite complex, southwestern Maine. Geological Society of America, Northeastern Section, Abstracts with Programs, 48.

Tucker, R.D., Råheim, A., Krogh, T.E., \& Corfu, F. (1987). Uranium-lead zircon and titanite ages from the northern portion of the Western Gneiss Region, south-central Norway. Earth and Planetary Science Letters, 81, 203-211.

van Elteren, J.T., Šelih, V.S., \& Šala, M (2019). Insights into the selection of 2D LA-ICP-MS (multi)elemental mapping conditions. Journal of Analytical and Atomic Spectrometry, 34, 1919-1931.

van Malderen, S.J.M., van Elteren, J.T., Šelih, V.S., \& Vanhaecke, F. (2018). Considerations on data acquisition in laser ablation-inductively coupled plasma-mass spectrometery with low-dispersion interfaces. Spetrochimica Acta Part B Atomic Spectroscopy, 140, 29-34. 
van Staal, C.R., Whalen, J.B., Valverde-Vaquero, P., Zagorevski, A., \& Rogers, N. (2009). PreCarboniferous, episodic accretion-related, orogenesis along the Laurentian margin of the northern Appalachians. Geological Society of London, Special Publications, 327, 271-316.

Vermeesch, P. (2018). IsoplotR: A free and open toolbox for geochronology. Geoscience Frontiers, 9, 1479-1493.

Verts, L.A., Chamberlain, K.R., Frost, C.D. (1996). U-Pb sphene dating of metamorphism: The importance of sphene growth in the contact aureole of the Red Mountain pluton, Laramie Mountains, Wyoming. Contributions to Mineralogy and Petrology, 125, 186-199.

Walters, J.B., \& Kohn, M.J. (2016). Protracted thrusting followed by late rapid cooling of the Greater Himalayan Sequence, Annapurna Himalaya, Central Nepal: Insights from titanite petrochronology. Journal of Metamorphic Geology, 35, 897-917.

Weinberg, R.F., Wolfram, L.C., Nebel, O., Hasalová, P., Závada, P., Kylander-Clark, A.R.C., \& Becchio, R. (2020). Decoupled U-Pb date and chemical zonation of monazite in migmatites: The case for disturbance of isotopic systematics by coupled dissolutionreprecipitation. Geochimica et Cosmochimica Acta, 269, 398-412.

West, D.P., Jr. (1999). Timing of displacements along the Norumbega fault system, south-central and south-coastal Maine. In A. Ludman, \& D.P. West Jr. (Eds.), Norumbega fault system of the northern Appalachians. Geological Society of American Special Paper, 331, 167178.

West, D.P., Jr., \& Hubbard, M.S. (1997). Progressive localization of deformation during exhumation of a major strike-slip shear zone: Norumbega fault zone, south-central Maine, USA. Tectonophysics, 273, 185-201.

Whitney, D.L., \& Evans, B.W. (2010). Abbreviations for names of rock-forming minerals. American Mineralogist, 95, 185-187.

Wing, B.A., Ferry, J.M., \& Harrison, T.M. (2003). Prograde destruction and formation of monazite and allanite during contact and regional metamorphism of pelites: Petrology and geochronology. Contributions to Mineralogy and Petrology, 145, 228-250.

Woodhead, J.D., Hellstrom, J., Hergt, J.M., Greig, A., \& Maas, R. (2007). Isotopic and elemental imaging of geological materials by laser ablation inductively coupled plasma-mass spectrometry. Geostandards and Geoanalytical Research, 31, 331-343.

\section{LIST OF SUPPORTING INFORMATION}

Appendix S1. Petrography of paragneiss sample SSP18-1D

Appendix S2. Major Element Thermobarometry

Table S1. Major and minor element compositions measured by EPMA.

Table S2. Titanite U-Pb data and associated ages. 
Table S3. Titanite trace element data.

Table S4. ${ }^{207} \mathrm{~Pb} /{ }^{206} \mathrm{~Pb}$ measurements of U-poor phases.

Table S5. U-Pb isotope ratio reproducibility of secondary reference materials.

Table S6. Major, minor, and trace element concentrations for secondary reference materials.

Table S7. LA-ICP-MS compositional data for major phases.

Table S8. Zr-in-titanite temperatures.

Figure S1. Photographs of outcrop-scale textures.

Figure S2. Garnet and biotite X-ray intensity maps.

Figure S3. Thin section-scale X-ray intensity maps of sample SSP18-1A.

Figure S4. Titanite LA-ICP-MS analysis locations for SSP18-1A, Grain 1

Figure S5. Titanite LA-ICP-MS analysis locations for SSP18-1A, Grain 2

Figure S6. Titanite LA-ICP-MS analysis locations for SSP18-1B

Figure S7. Titanite EBSD map of Grain 1, SSP18-1A.

Figure S8. Titanite EBSD map of Grain 2, SSP18-1A.

Figure S9. Photomicrographs of paragneiss sample SSP18-1D.

Figure S10. Garnet transect data for sample SSP18-1D.

Figure S11. Summary of EPMA compositional data for samples SSP18-1A and -1B.

Figure S12. Thin section-scale photomicrograph for SSP18-1B.

Figure S12. Major element thermobarometry results for Sample SSP18-1D. 